\title{
دور مديري المدارس في التربية علي المواطنة بمدارس التعليم الأساسي بسلطنة عُمان الموان
}

الباحث/ حميد بن مسلم بن سعيد السعيدي

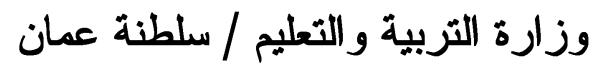

\section{ملخص الدراسة}

هدفت الدر اسة إلى التعرف على دور مديري الددارس في التربية على المو اطنة بمدارس التعليم الأساسي بسلطنة عُمان من وجهة نظر هم، بالإضافة إلى معرفة أثر متغير ات النو ع و المؤهل العلمي و المرحلة الدراسية.

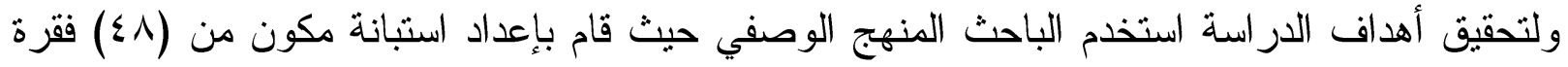

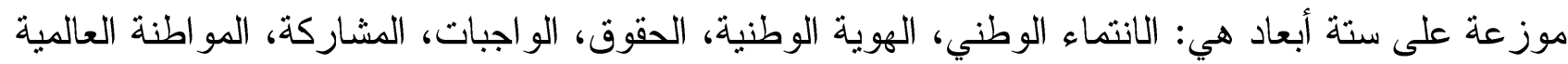

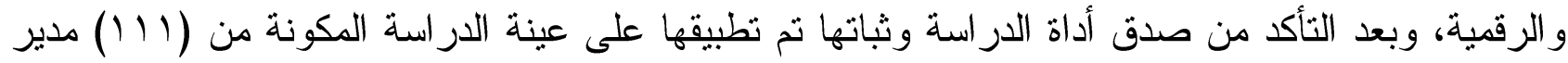
ومديرة من مديري المدارس التعليم الأساسي وما بعد التعليم الأساسي، اختيار هم بالطريقة العشو ائية البسيطة.

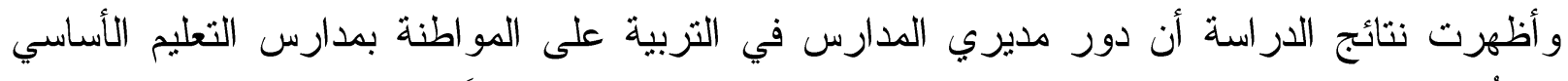

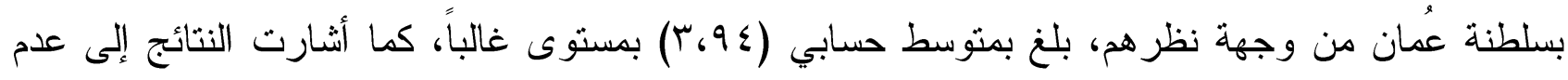

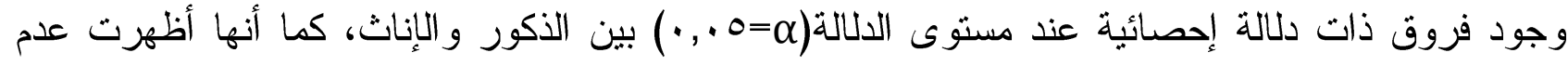

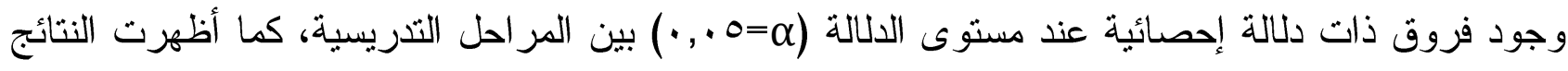

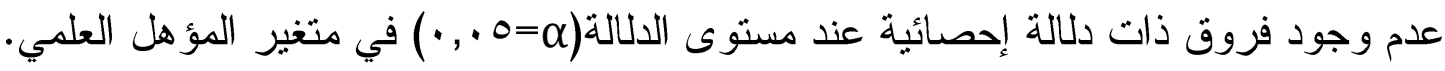

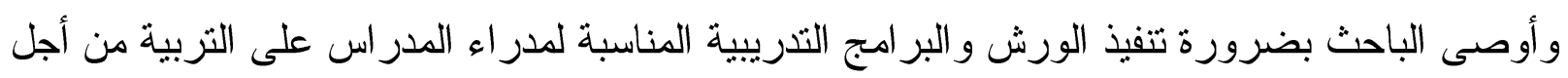
المو اطنة، كما قدم مجموعة من المقترحات للار اسات المستقبلية. مقدمة الدر اسة ومشكلتها:

تُعتبر المدرسة المؤسسة الثزبوية الأكثر تأثير على المتعلم، والأكثر مقدرة على تحقيق الثزبية على المو اطنة، لما لها من مقدرة متتوعة من خلال خلق مو اقف تعليمية تسهم في تكريس الو اقع الحقيقي و المثالي للمو اطنة، مما يسهم بدرجة كبيرة في تربية المتعلمين على الغايات الأساسية للمو اطنة.

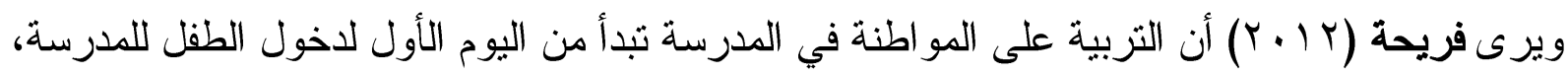

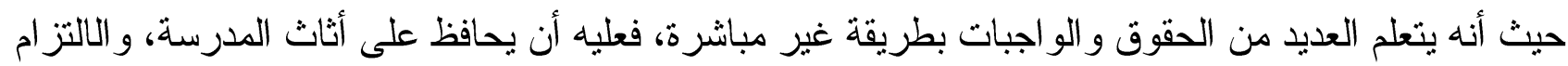

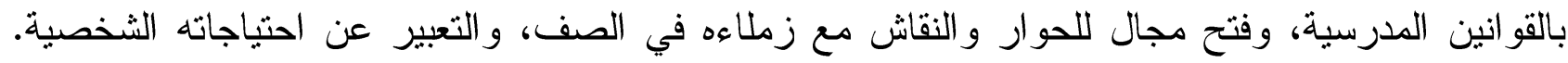

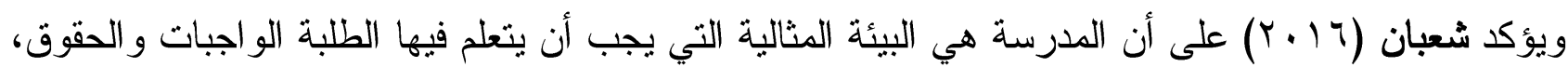

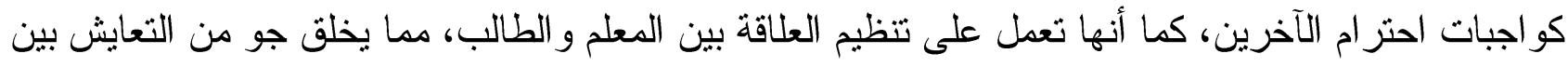


حيث يكتسب الطلبة من خلال ذلك التفاعل كل القيم والاتجاهات و الواجبات الوطنية من خلال ما يشاهده من مو اقف تربوية. إذ تبلغ المدرسة أقصى درجات الفاعلية في التربية على المواطنة عندما تتطابق منهاجها

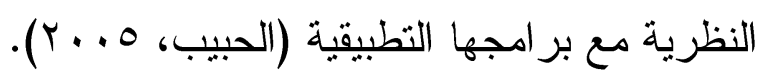

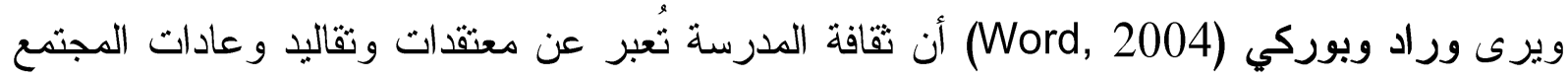

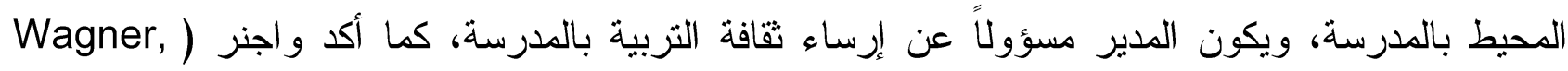

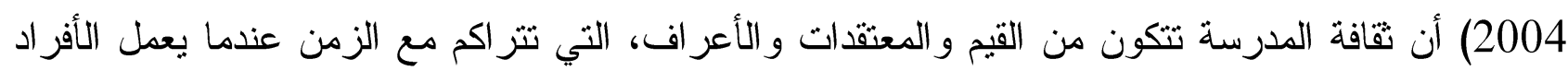

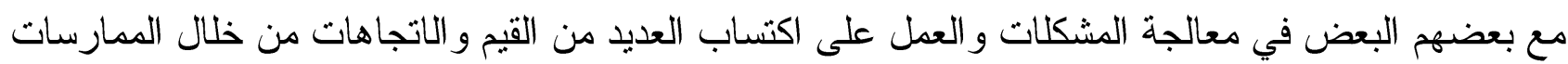
الحقيقية للسلوكيات الإيجابية.

لذا تعتبر القيادة الددرسية الحديثة الأكثر مقدرة على تحقيق أهداف التعلم، فلم يعد دور ها مقصوراً على لمانى

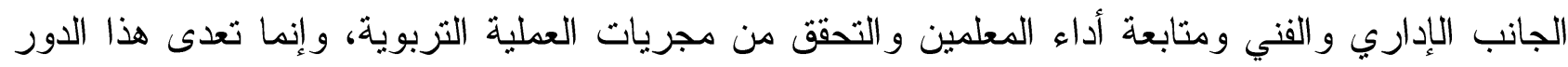

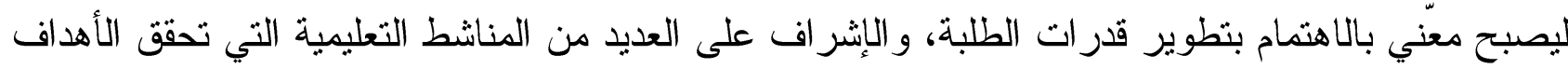

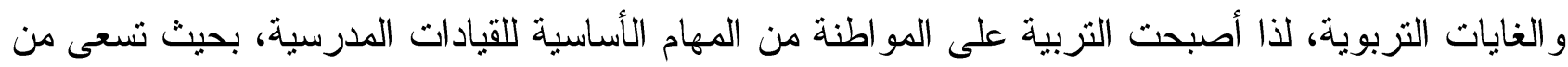
خلالها إلى إيجاد المواطن المسؤول. و إذ أن دور القيادة المدرسية في تحقيق الأهداف الوطنية يرتبط بما يقوم به من أدوار في متابعة أداء

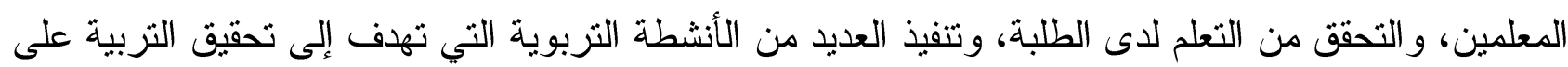

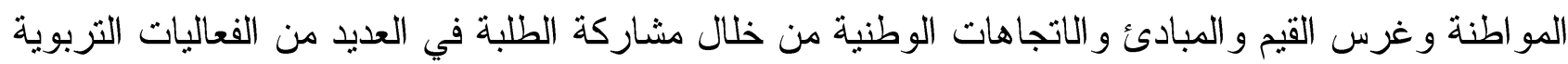

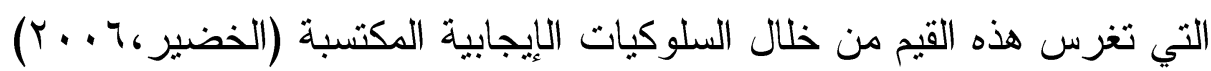
و هذا الدور لمديري المدراس يتعدى إلى الإسهام في تحقيق التتمية الثشاملة في المجالات الاجتماعية،

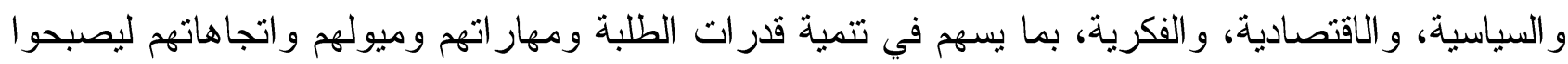

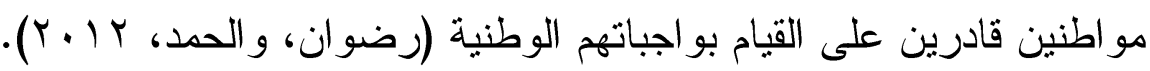

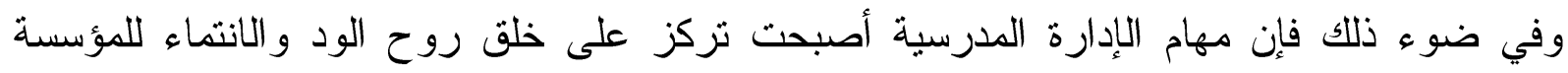

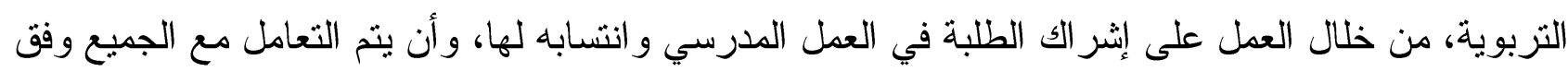

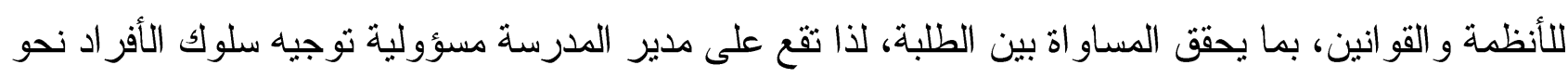

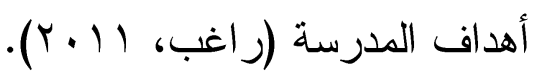
ويتضح من ذلك الإدارة المدرسية في العصر الحديث اتجهت إلى تحقيق التربية على المواطنة من خلال

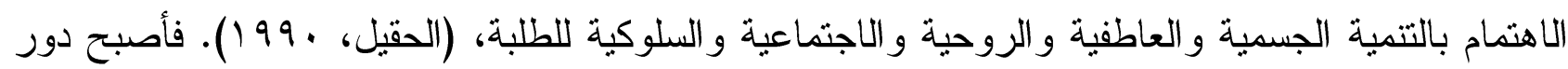

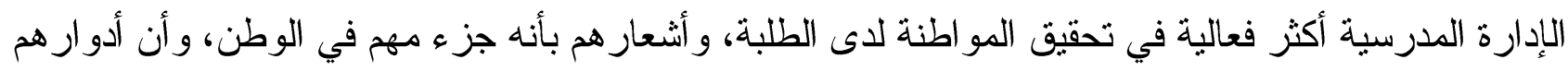

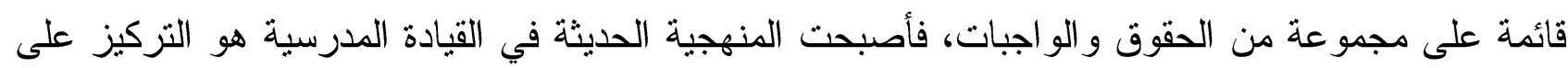
التربية على المو اطنة، من خلال تبني الخطط و الرؤى التربوية التي يعتد بها في رسم سياسة التعليم.

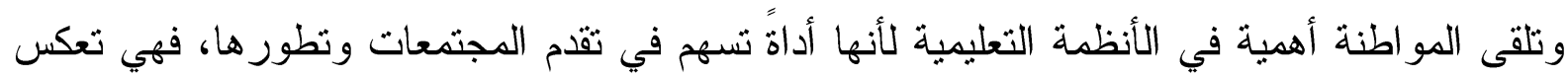
العادات و التقاليد و القيم و الاتجاهات الإيجابية، ويحظى موضوع المواطنة بأهمية بالغة في مسيرة الحضارة 
الإنسانية، (المعمري، الغريبية، 2012)، وتركز المواطنة على مخاطبة ذات الفرد، لتمده بالمعارف اللازمة

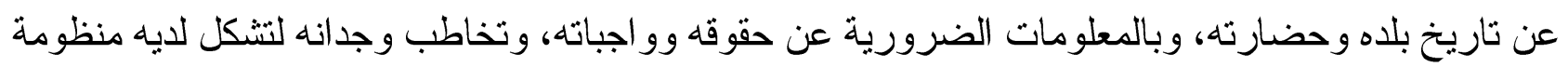

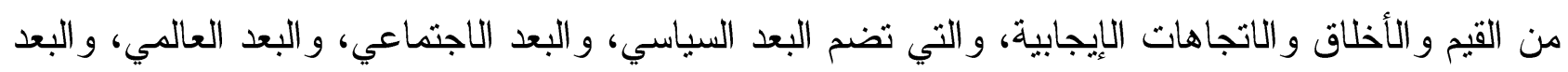

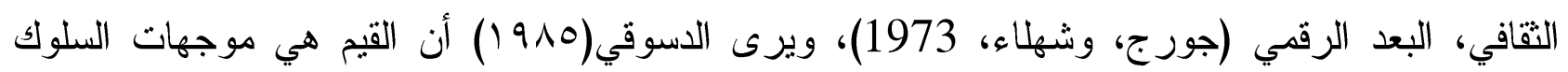
وضو ابطه، وهي حر اس الأنظمة وحامية البناء الاجتماعي، فخطرها وفي في حياة المجنمعات كبير .

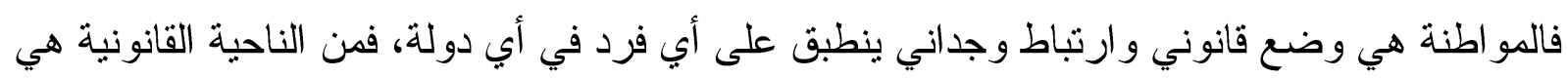

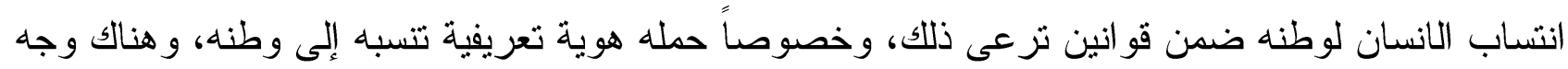

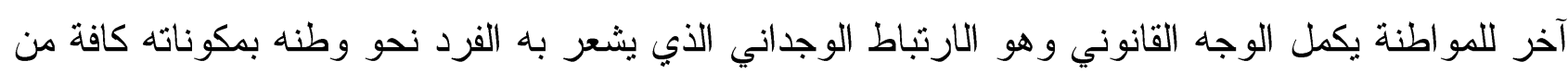

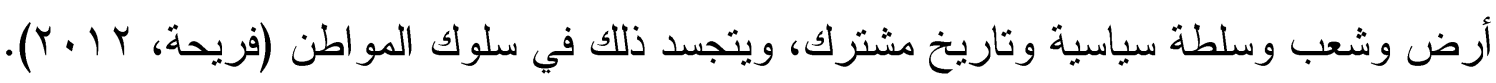

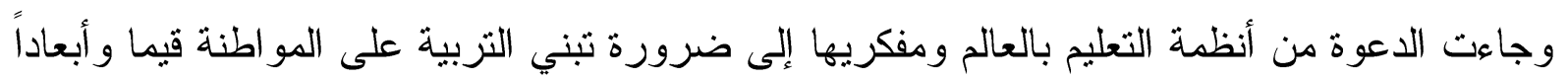

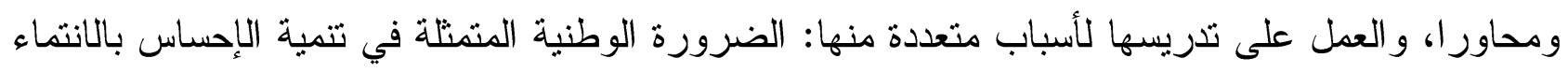

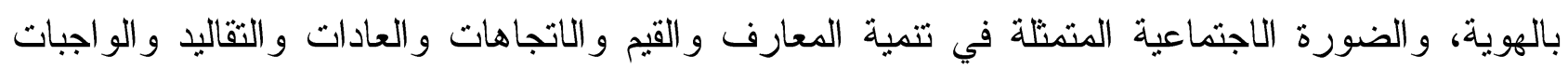

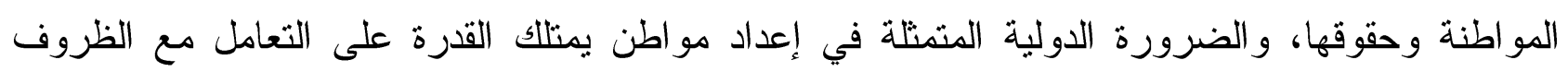

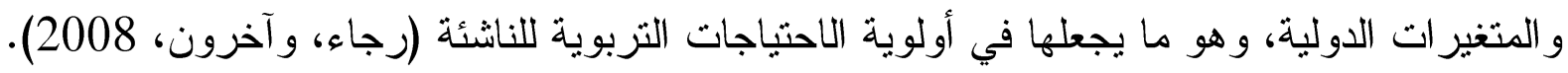

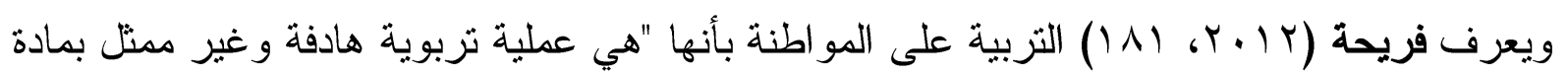
در اسية و احدة كونه يهنم بتتشئة الطالب-المو اطن، وتتكيل شخصيته المعرفية و الأخلاقية و الاجنماعية و الوطنية".

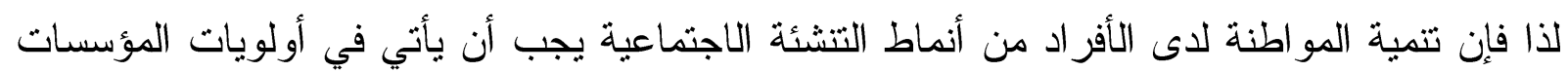

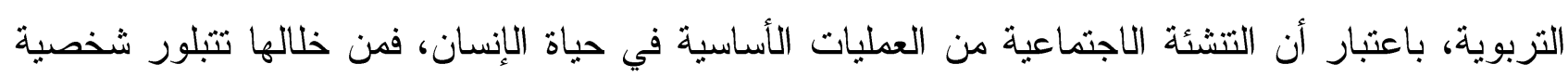
الفرد(الحامد، (2004). وتُعد التربية على المو اطنة من أهم سبل مو اجهة تحديات القرن الحادي و العشرين، سيما في ظل التغيرات

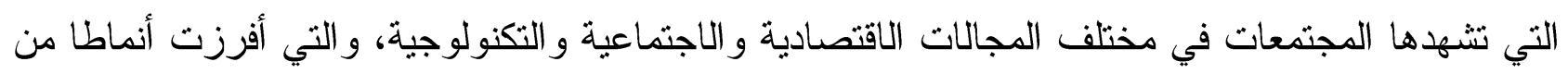

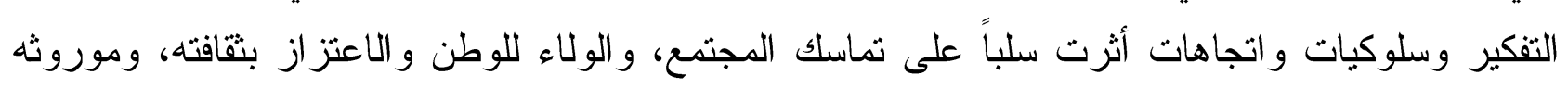

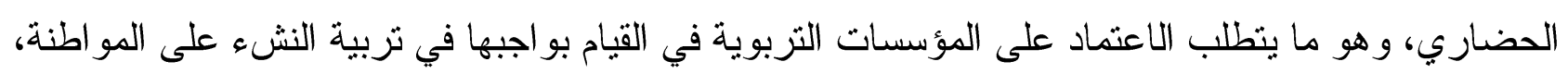
و إيجاد المواطن المسؤول المرتبط بوطنه (السعيدي، 2013).

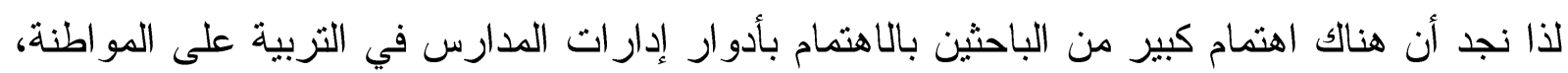

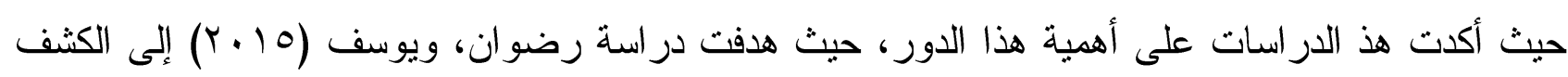
عن تصورات مديري المدراس الحكومية للمعيقات التي تو اجه تطبيق خطة النهوض الوطني لتعزيز الانتماء

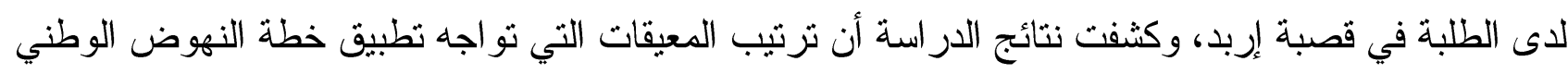
لتعزيز الانتماء جاءت كالآتي: المعيقات المادية، ثم المعيقات الاجتماعية، قم العيقات الفنية، أما المعيقات الإدارية فاحتلت المرتبة الر ابعة. 
و أجرى القاسم، وعاشور (10 ب ب) در اسة هدفت إلى معرفة دور مديري المدارس الحكومية في محافظة

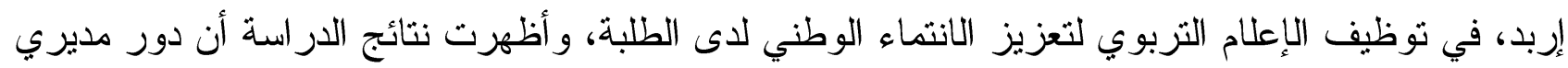

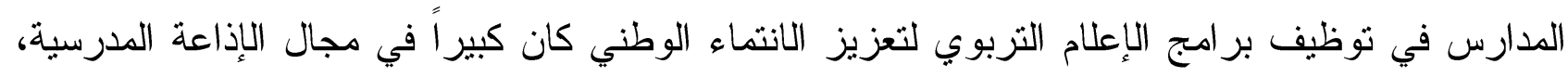

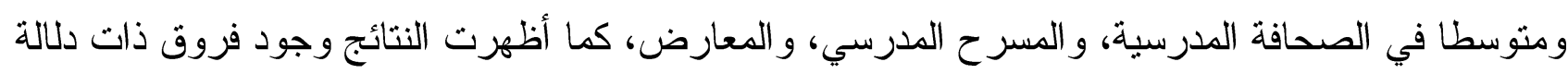
إحصائية تعزى لمتغير الجنس و المسمى الوظيفي.

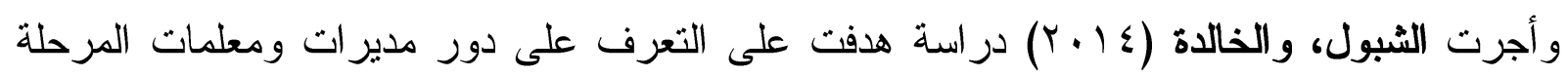
الأساسية في تعزيز مفاهيم المواطنة لدى الطالبات في المدارس الأساسية، وكثفت نتائج الدراسة أنس أن مفاهيم

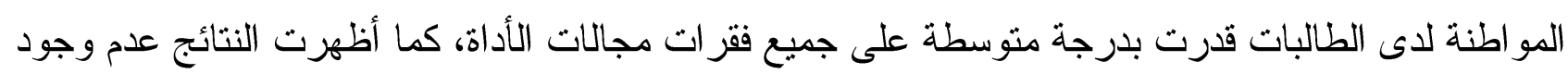

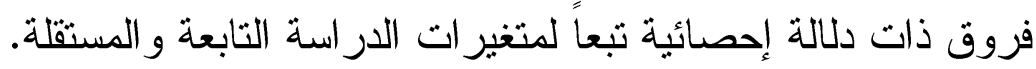

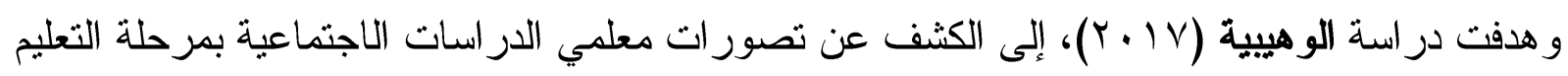

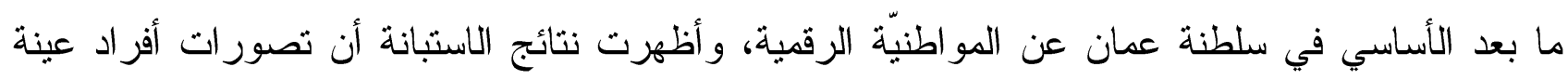

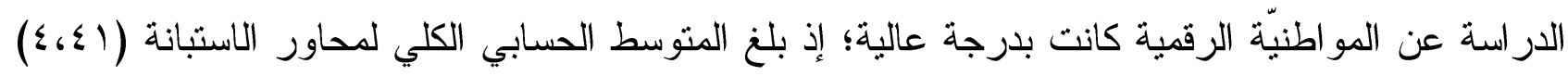

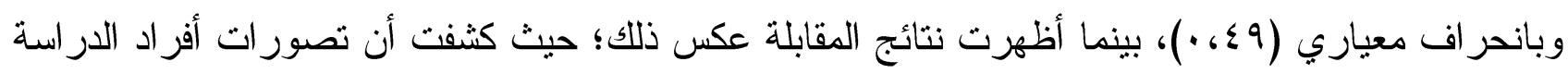
كانت غير و اضحة عن المو اطنيّة الرقمية.

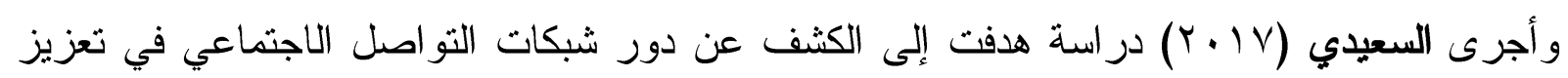

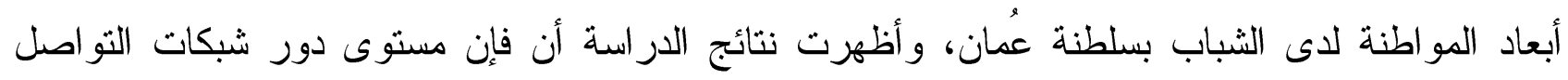

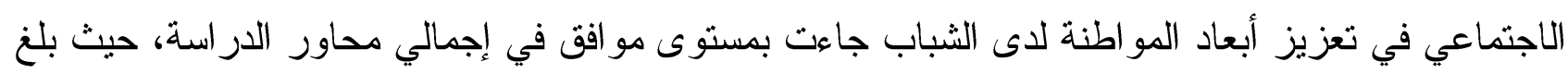

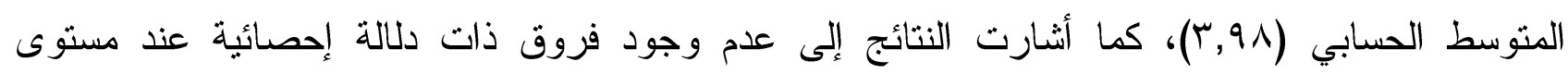

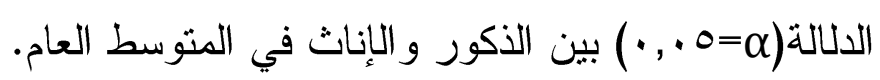

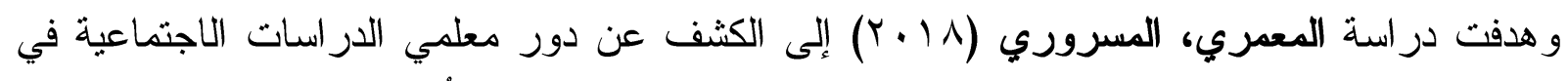

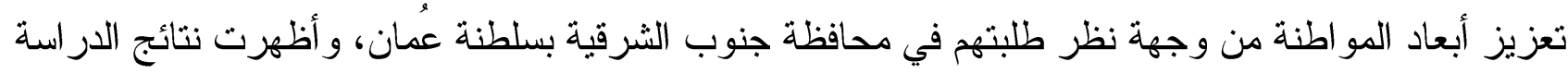

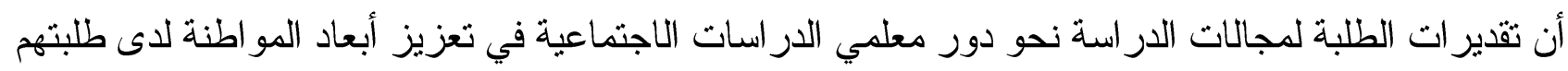

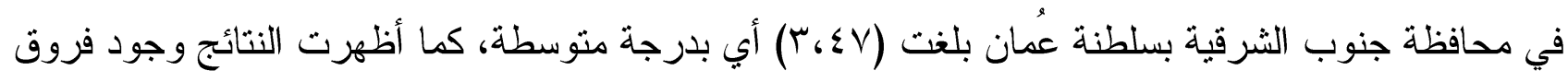

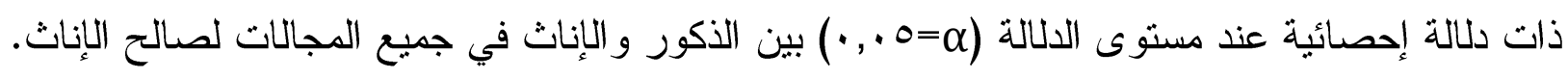

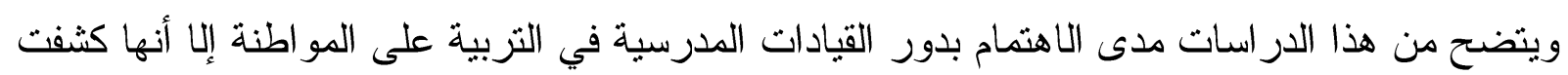

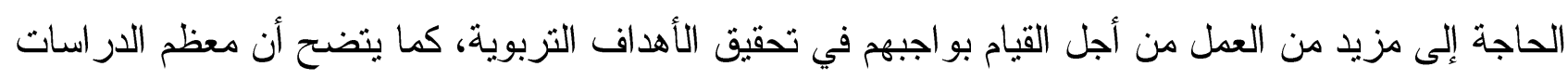

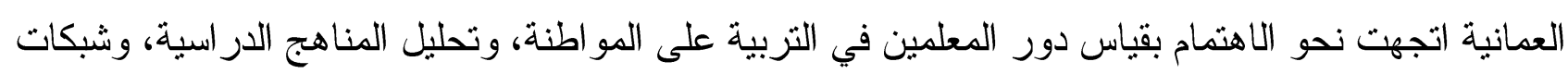

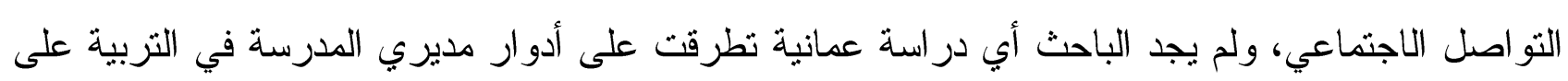

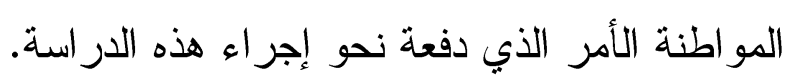

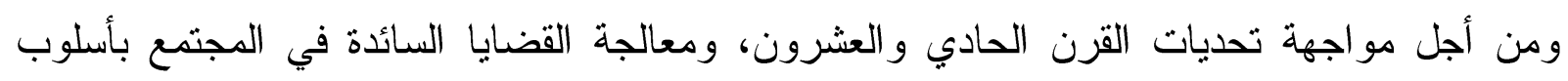

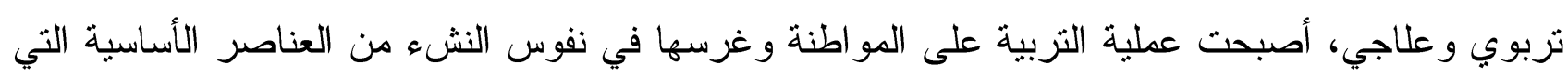


يجب أن نقوم بها المؤسسات التربوية، و المجتمعية، والدينية، لأنها لا تتم من خلال المناهج الدراسية، والكتب

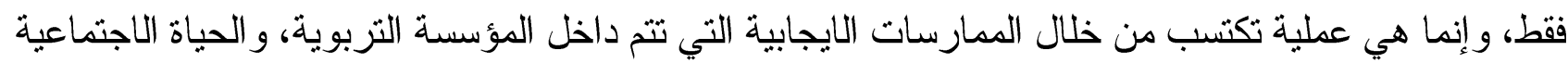
التي يتو اجد بها الفرد.

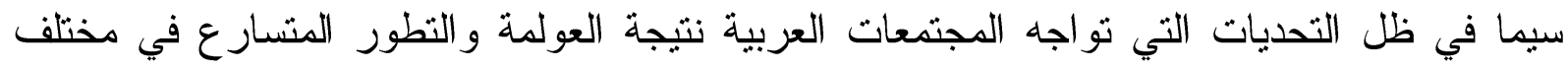

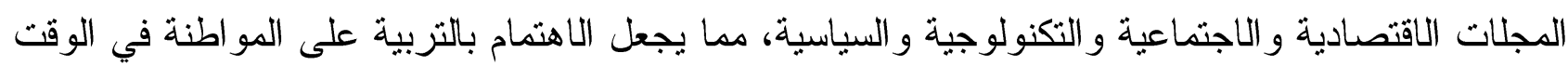

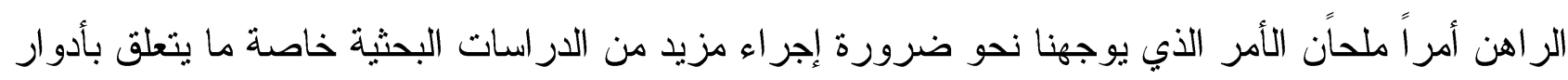

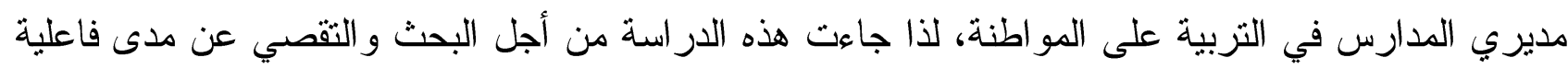
أدائهم.

مشكلة الدر اسة و أسئلتها:

تمثل التربية على المو اطنة أحد أهم الأهداف الأساسية التي تقوم عليها فلسفة التعليم العمانبة، خاصة

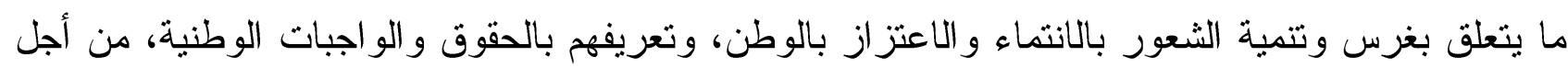

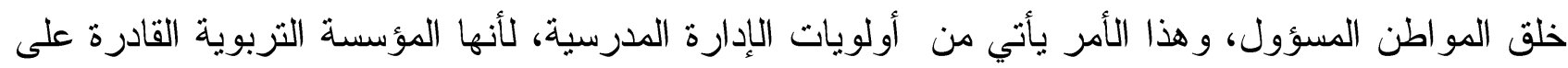

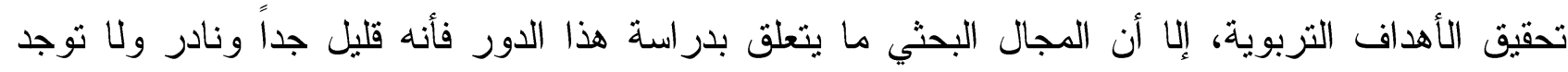

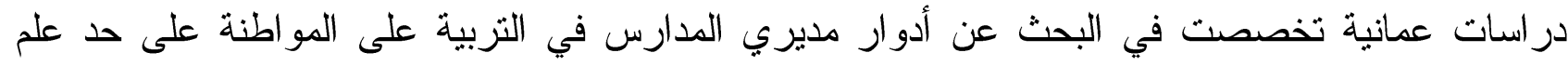
الباحث، إذ أن معظم الدراسات العمانية ركزت على أدو ار المعلمين و على قياس مدى تضمين الثين المناهج العمانية

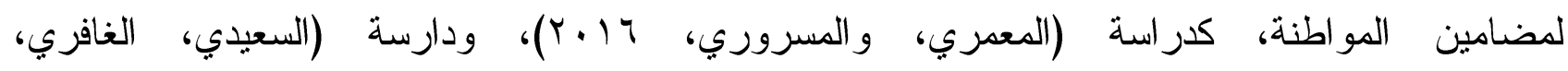

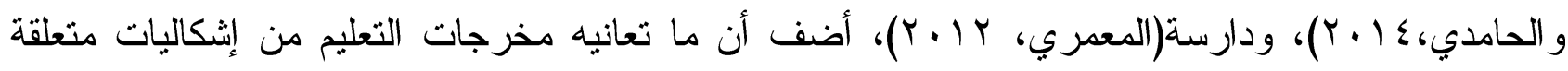

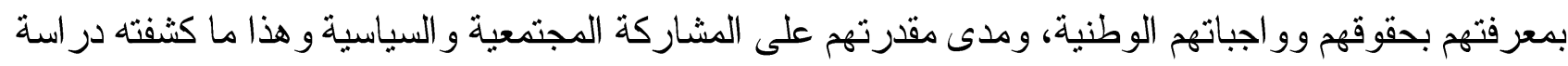

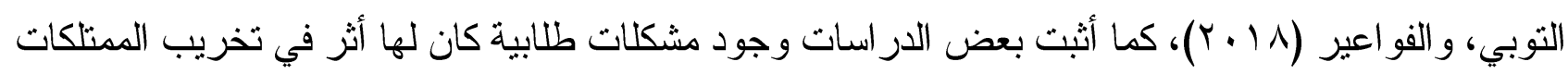
العامة، وظاهرة العنف والتتمر المدرسي، وظاهرة الغش، والتسرب من المدرسة، و انتشار سلوكيات خاطئة

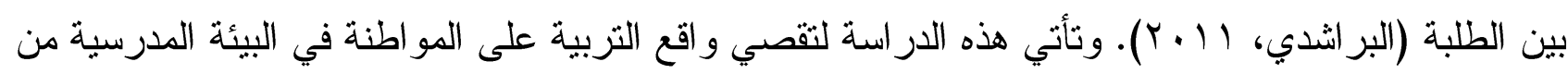

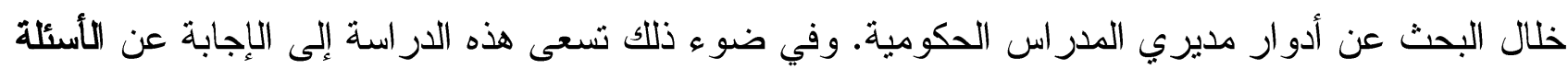

ا. ـ ما دور مديري المدارس في التربية على المواطنة بمدارس التعليم الأساسي في سلطنة عمان من وجهة

نظر هم؟ r. هل توجد فروق ذات دلالة إحصائية بين دور مديري المدارس في التزبية على المواطنة بمدارس التعليم

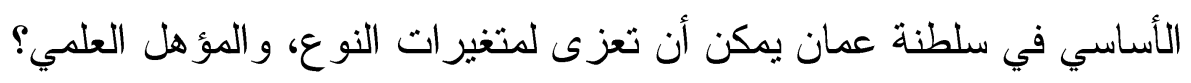

أهداف الدر اسة:

تسعى هذه الدراسة إلى تحقيق الأهداف التالية: ا. التعرف على دور مديري الددارس في التربية على المو اطنة بمدارس التعليم الأساسي في سلطنة عمان. 
r. الكثف ما إذا كانت هناك فروق ذات دلالة إحصائية بين دور مديري الددارس في التربية على المو اطنة

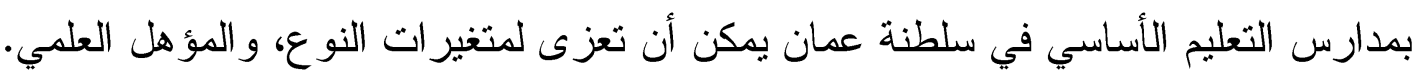

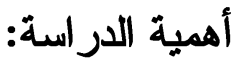

$$
\text { تكمن أهمية هذه الدر اسة في أنها: }
$$

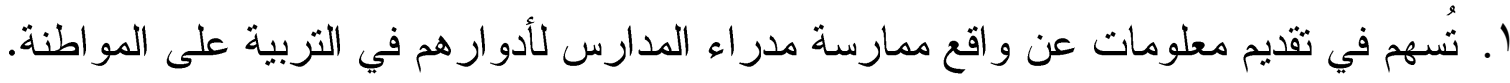

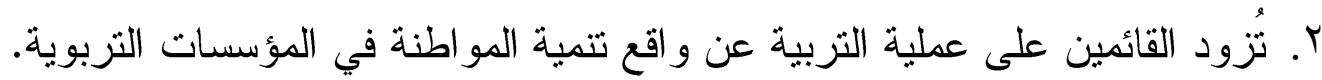

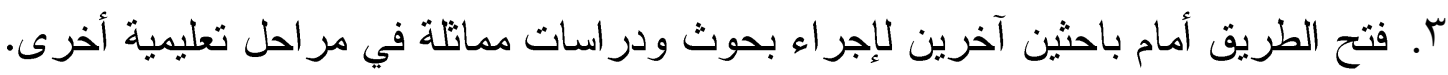

حدود الدر اسة:

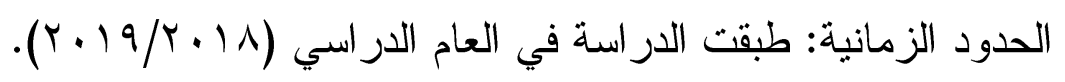

الحدود المكانية: اقتصرت الدراسة على عينة من مدارس الحلقة الثانية للتعليم الأساسي (ب- (- (1)،

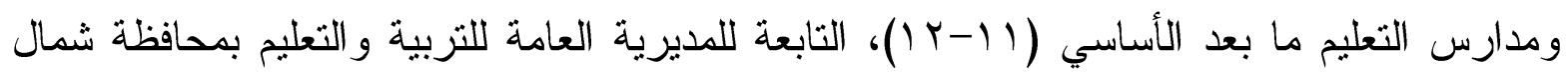
الباطنة، ومحافظة مسقط، ومحافظة الداخلية. الحدود البشرية: طبقت الدراسة على مديري الددارس بالتعليم الأساسي. • الحدود الموضو عية: ركزت الدراسة على التربية على المو اطنة.

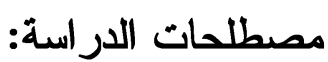

مديرو المدارس: موظفين إداريين يعملون على إدارة المدارس من أجل تحقيق أهدافها، من خلال القيام بمهامهم الوظيفية بالاعتماد على التخطيط و التنفيذ و المتابعة و التقييم.

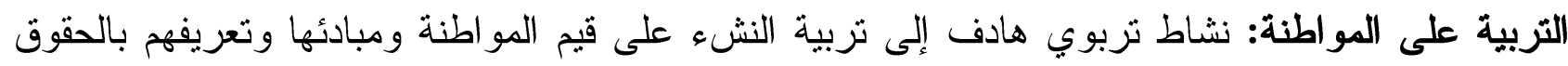
و الواجبات وغرس فيهم الانتماء الوطنية.

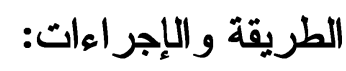
مجتمع الدر اسة:

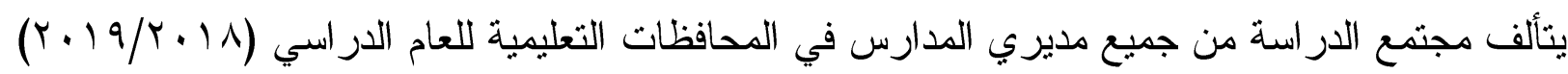

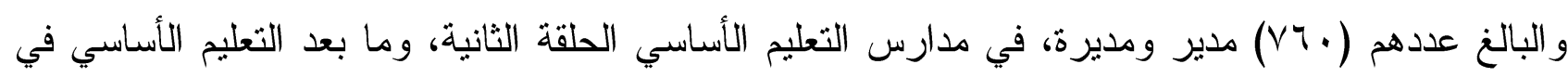
المدر اس الحكومية بسلطنة عمان. عينة الدراسة تكونت عينة الدر اسة من (111) مدير ومديرة، ويشكلون ما نسبته (T,؛؛ (1\%) من المجتمع الأصلي، وتم اختيار هم بالطريقة العشو ائية البسيطة، وهي الطريقة المناسبة نظر الحجم الحم المجتمع. منهج الدراسة: اعتمد الباحث في الدراسة المنهج الوصفي، والذي يعتبر مناسباً لهذا النوع من الدراسات، وذلك عن طريق وصف الظاهرة من خلال جمع البيانات ميدانية حولها بو اسطة أداة الاستبانة. أداة الدر اسة (الاستبانة) 
لتحقيق أهداف الدراسة قام الباحث بإعداد أداة الاستبانة وذلك بهدف الكثف على دور مديري مدارس التعليم

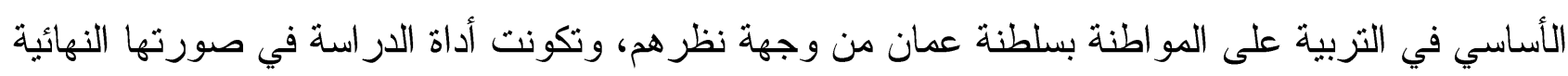

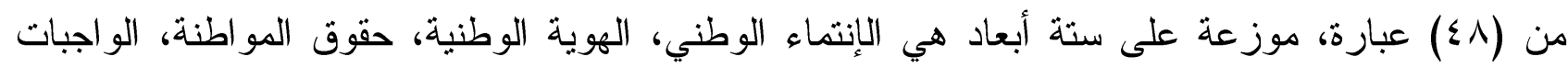

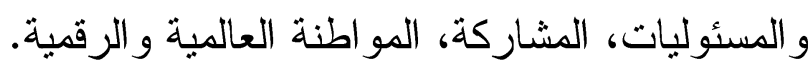
المقياس المعتمد في الأداة: تم استخدام مقياس التذرج الخماسي حسب نظام ليكرت (Likert) للاستجابات أفراد العينة في للأبعاد المواطنة على النحو المبين في الجدول (1)

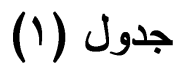

درجات المقياس المعتمد لثقديرات درجة التوظيف لاستجابات أفر اد العينة في أداة الاستبانة.

\begin{tabular}{|c|c|}
\hline درجة التوظيف & درجات مقياس ليكرت (Likert) \\
\hline دائما & 0 \\
\hline غالباً & $\varepsilon$ \\
\hline 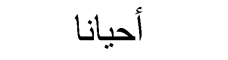 & $r$ \\
\hline نادراً & r \\
\hline أبداً & 1 \\
\hline
\end{tabular}

صدق الأداة:

للتحقق من صدق أداة الاستبانة استخدم الباحث صدق المككمين من خلال عرض الاستبانة على مجموعة

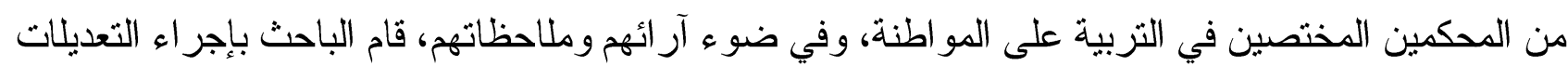

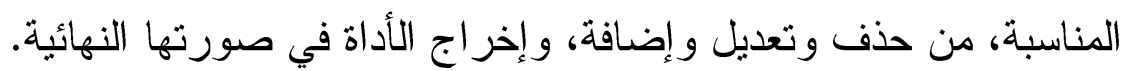
ثبات الأداة:

للتأكد من ثبات الأداة، قام الباحث بتطبيق الاستبانة على عينة تجريبية بلغت (0) مدير ومديرة، وكانت

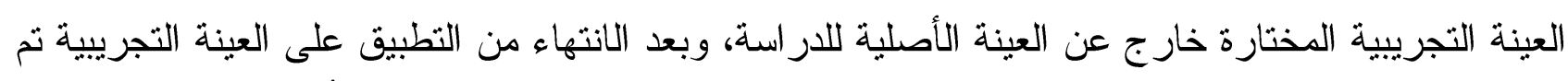

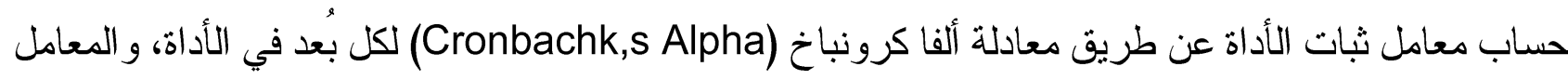

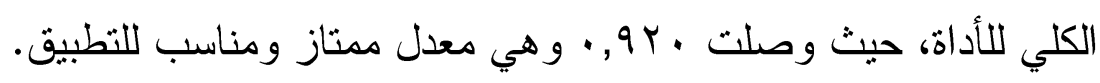
إجر اءات تطبيق الدراسة:

بعد تحديد مشكلة الدراسة، وأسئلتها ومتغير اتها، وبعد الانتهاء من إعداد أداة الدر اسة، و التأكد من صدقها

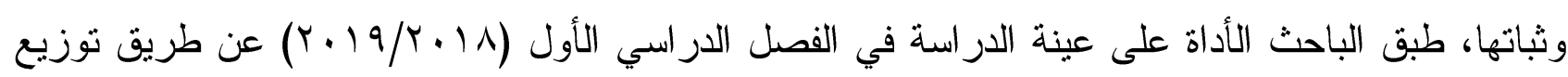

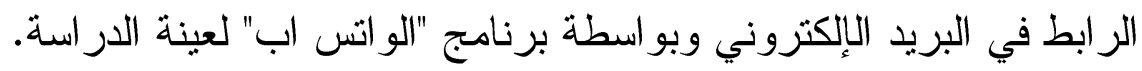

المعالجة الإحصائية:

لتحقيق أهداف الدر اسة استخدم الباحث الأساليب الإحصائية (SPSS) في تحليل البيانات التي تم جمعها بعد تطبيق أداة الدر اسة وهي: معامل الثبات ألفا كرونباخ، و المتوسطات الحسابية و الانحر افات المعيارية و الأهمية 
النسبية (الرتبية)، واختبار(ت)(t-test)، وتم توظيف المعيار الإحصائي الموضح في الجدول (؟) لتنسير

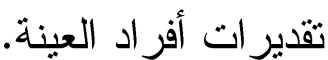

جدول (广) (بر)

\begin{tabular}{|c|c|c|}
\hline درجة التوظيف & مدى الدرجات & الدرجة \\
\hline دائما & $0_{6} \cdot-\varepsilon_{6} 0$. & 0 \\
\hline غالباً & $\varepsilon_{6} \leqslant q-r_{6} 0$. & $\varepsilon$ \\
\hline أحيانا & $r_{6} \leqslant q-r_{6} 0$. & 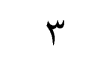 \\
\hline 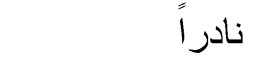 & $r_{6} \leqslant q-1,0$. & r \\
\hline أبداً & $16 \leqslant 9-16$. & 1 \\
\hline
\end{tabular}

نتائج الدر اسة ومناقشتها: نتائج السؤ ال الأول ومناقشتها: للإجابة عن هذا السؤال ونصد: ما دور مديري المدارس في التربية على المواطنة بمدارس التعليم الأساسي

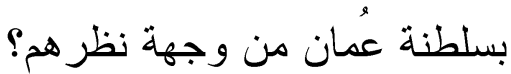
تم استخر اج المتوسطات الحسابية و الانحر افات المعيارية لجميع أبعاد أداة الاستبانة و البُعد العام حيث تم ترتيبها ترنيبا تتازلياً كما هو و اضح في الجدول (r)

\section{جدول (r)}

المتوسطات الحسابية و الانحر افات المعيارية أبعاد أداة الاستبانة للمتوسط العام للار اسة

\begin{tabular}{|c|c|c|c|c|}
\hline درجة التوظيف & المعياري الحر اف & الحسابي & أبعاد التزبية على المو اطنة & s \\
\hline دائما & $\cdot, \varepsilon$ & $\{, 0 \wedge$ & الهوية الوطنية & 1 \\
\hline غالباً & $\cdot, \mu \wedge$ & $\varepsilon, \varepsilon Y$ & الحقوق & r \\
\hline غالباً & • & $\varepsilon, Y \varepsilon$ & 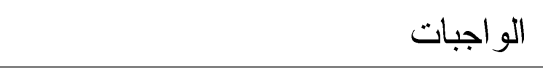 & r \\
\hline غالباً & • & r,Ar & الإنتماء الوطني & $\varepsilon$ \\
\hline 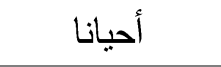 & $\cdot, \leqslant 0$ & $r, \leqslant T$ & المشاركة & ○ \\
\hline أحيانا & $r, 1$. & $r, 1 \cdot$ & المو اطنة العالمية و الرقمية & 7 \\
\hline غالباً & $\cdot, r V$ & ५, q & المتوسط العام & \\
\hline
\end{tabular}

يتضح من الجدول (r) أنه على المستوى العام فإن دور مديري المدارس في التربية على المواطنة

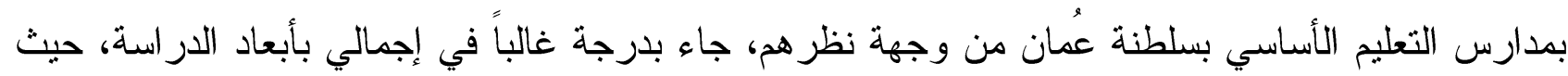
بلغ المتوسط الحسابي (؟ (؟, ب). 


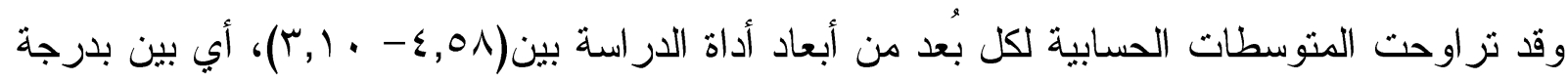

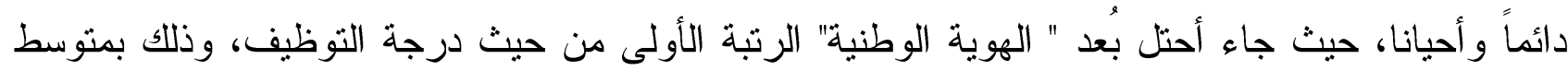

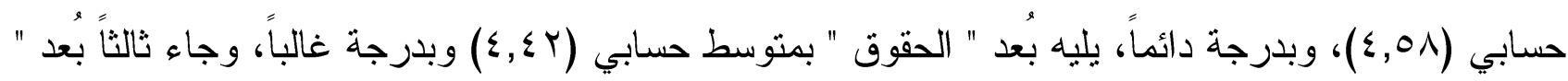

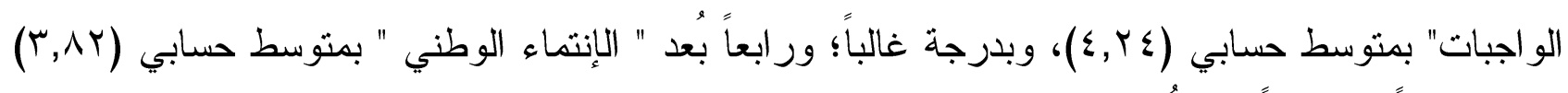

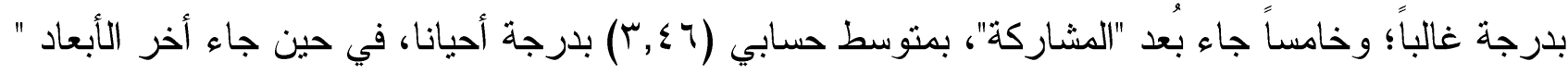

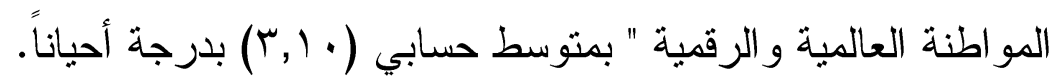

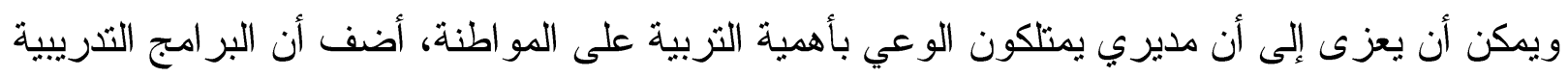

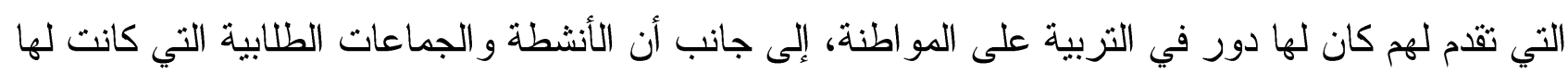

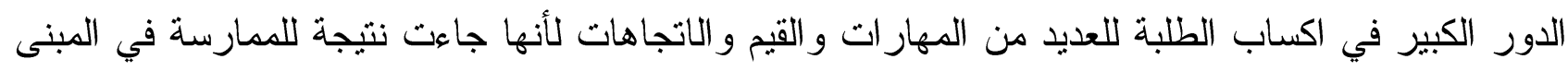

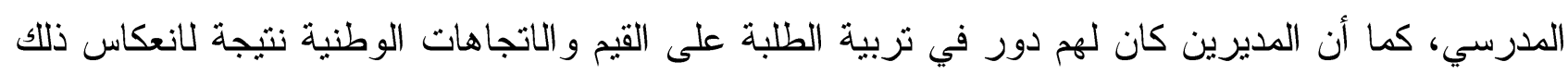

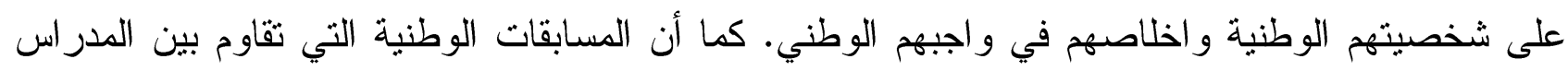

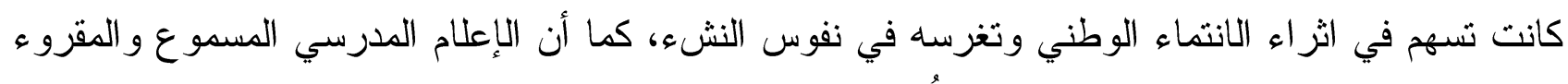
كان من بين العوامل التي ساهمت في هذا البعد.

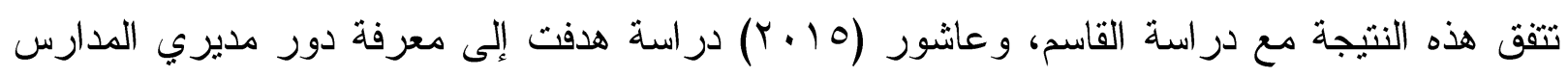

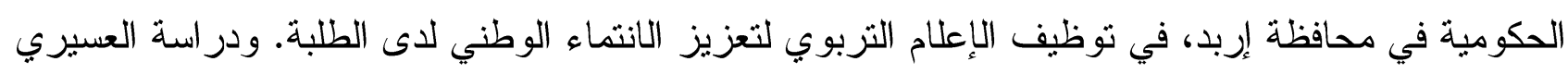

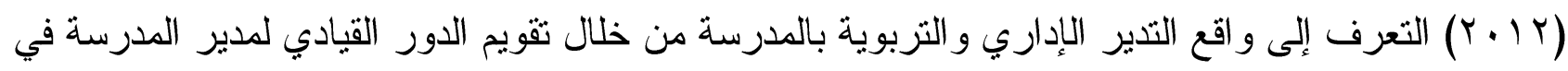
تتمية المو اطنة و السلوك المدني داخل المجتمع المدرسي.

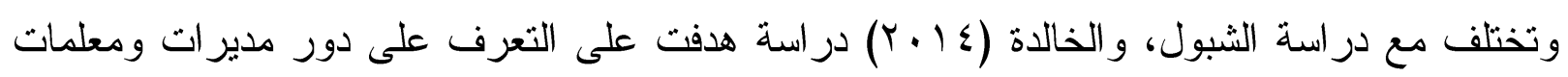

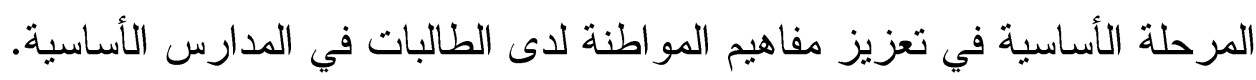

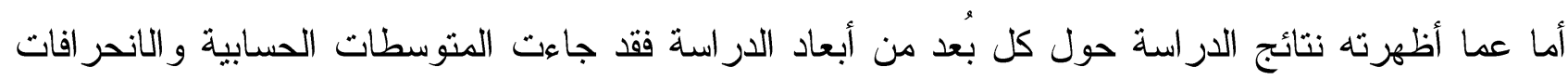

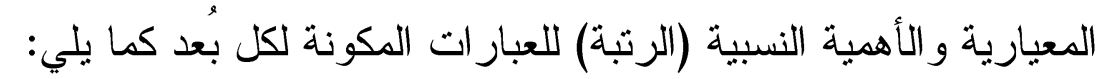

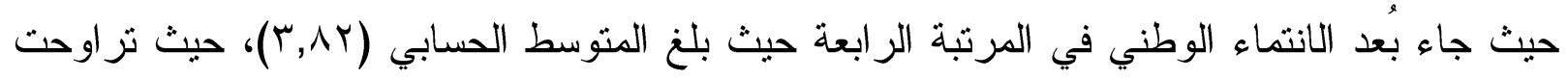

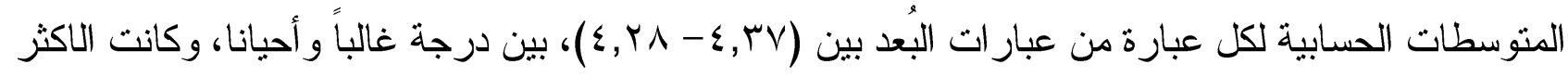

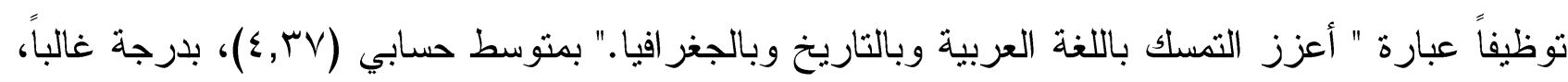

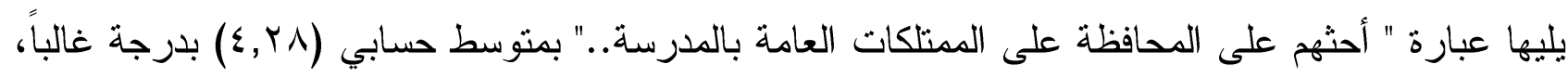

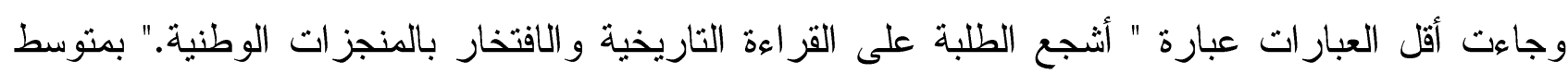

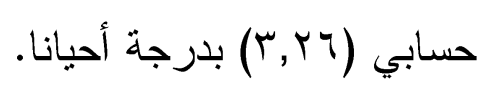

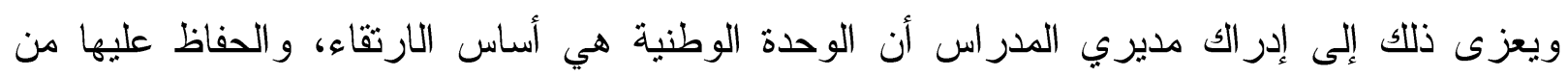

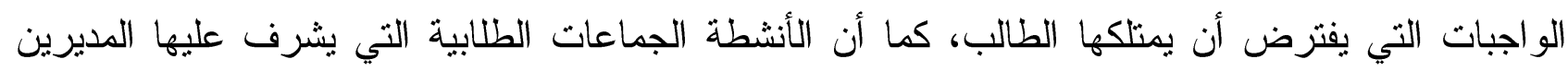
أسهمت في تتمية الولاء و الانتماء الوطني. 
في حين جاء بُعد الهوية الوطنية في المرتبة الأولى حيث بلغ المتوسط الحسابي (1,01))، وتراوحت

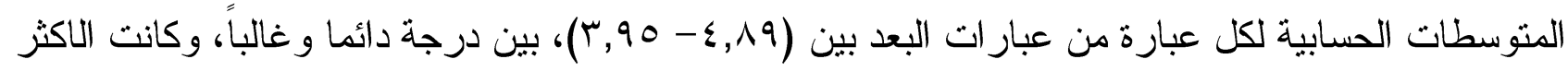

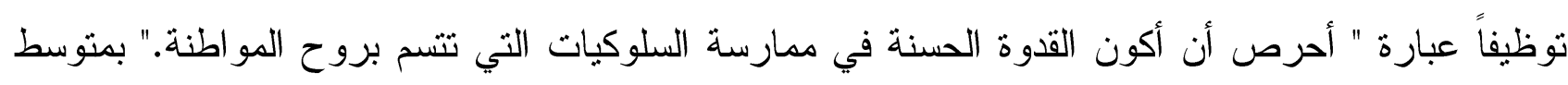

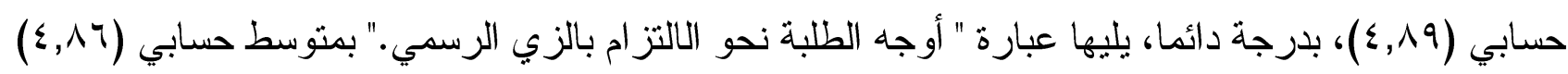

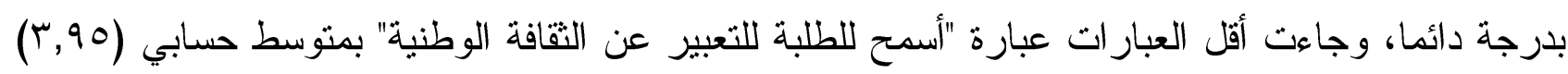
بدرجة غالباً. ويعزى ذلك إلى أن الأنظمة المدرسية قائمة على مجموعة من القوانين أن تركز على الهوية الوطنية و التي

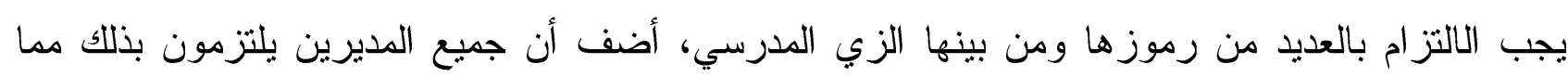

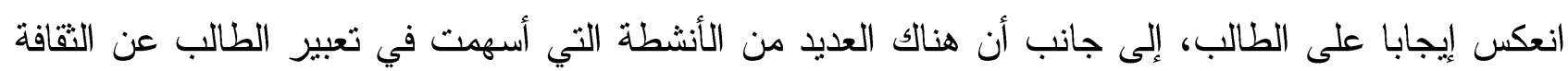
الوطنية من خلال الممارسة في الأنشطة الطلابية.

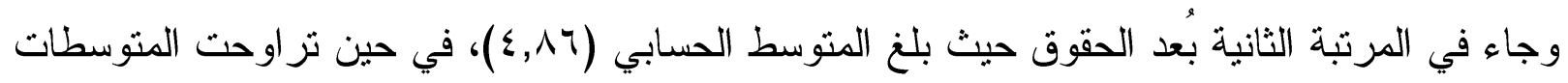

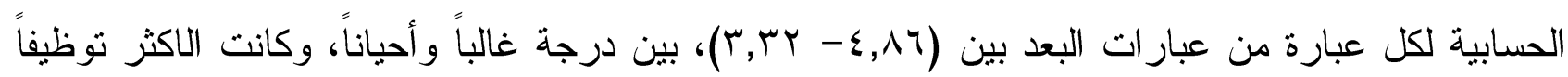

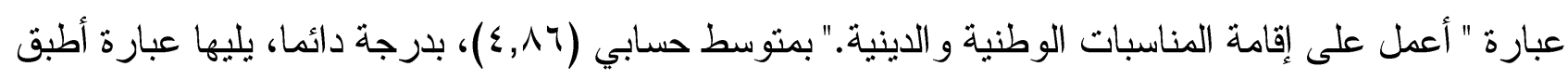

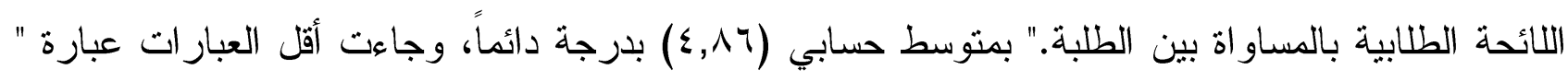

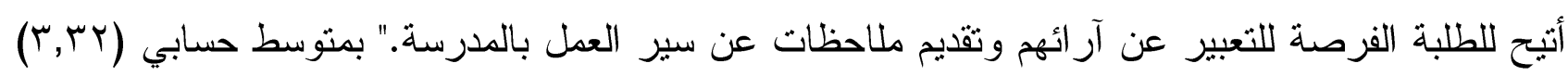
بدرجة أحياناً.

ويعزى ذلك إلى إدراك المديرين أن حقوق المواطنة كانت من بين اهتماماتهم في توفير كل الاحتباجات

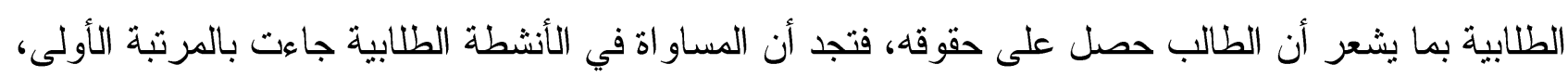

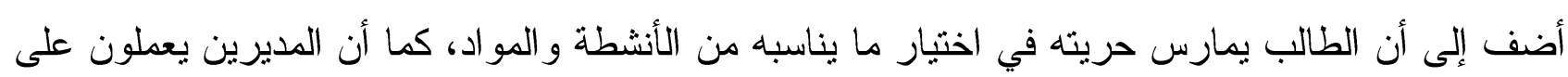
إعطاء الطلبة حق المشاركة وإبداء الر أي في المناشط المدرسية وهذا يسهم في التعرف الطلبة على الممارسات الو اضحة لهم. وجاء في المرتبة الثالثة بُعد الو اجبات حيث بلغ المتوسط الحسابي (ع ب, ع)، أما المتوسطات الحسابية لكل

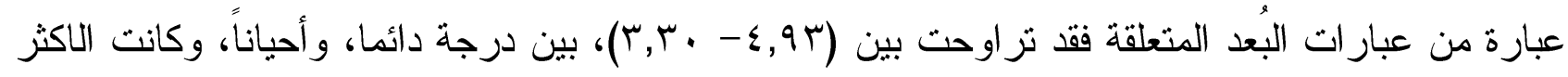

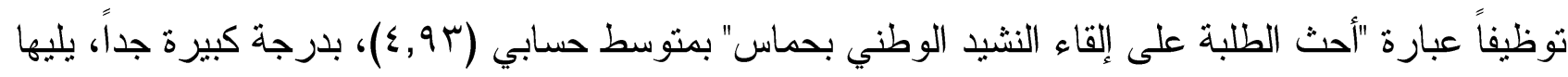

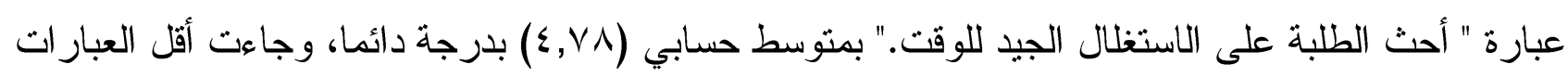

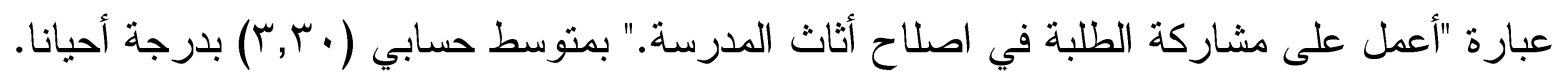

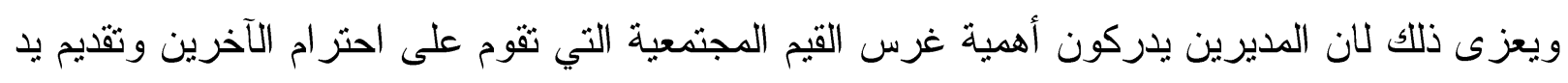
العون و المساعدة و هذه نتيجة للتوجيهات الإيجابية لاى المعلمين، ودور هم في القيام بو اجباتهم مما يسهم في لئي

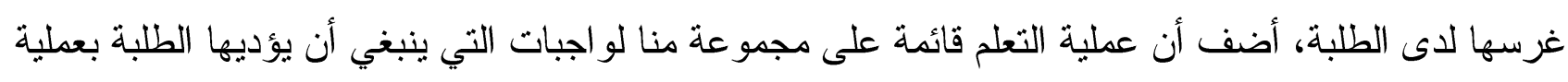

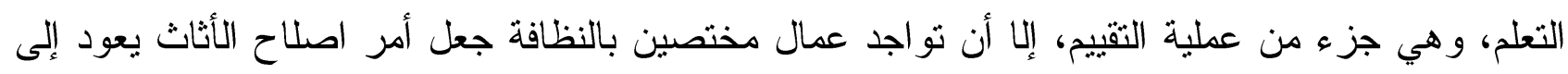
مهامهم، أكثر من أن يقوم به الطلبة. 
في حين جاء بُعد المشاركة في المرتبة الخامسة حيث بلغ المتوسط الحسابي (ٓح, ب)، أما المتوسطات

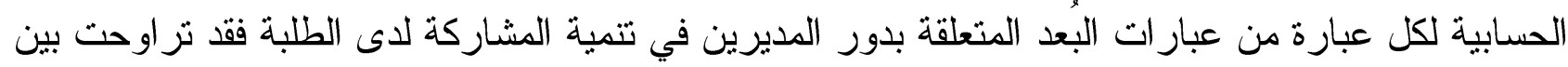

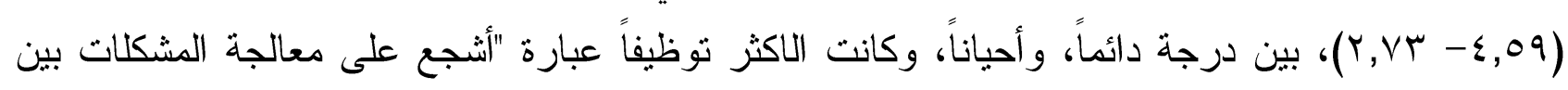

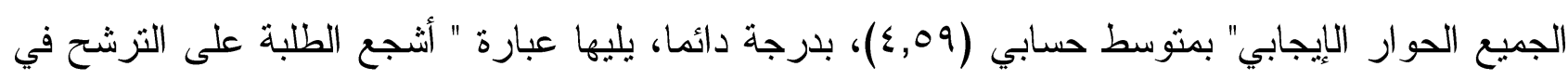

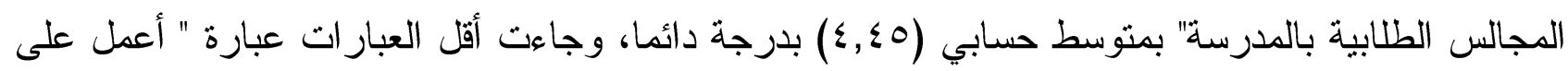

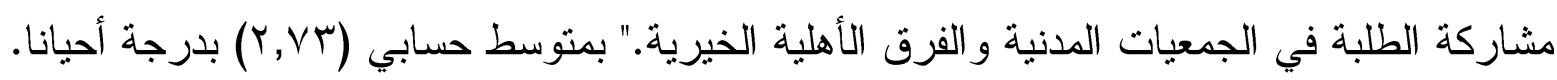

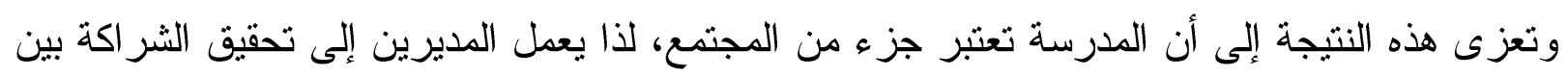

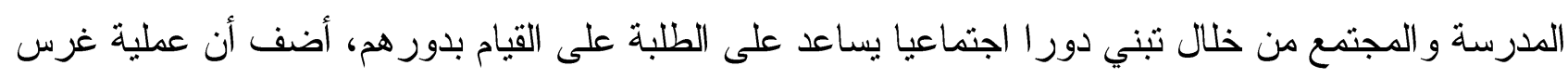

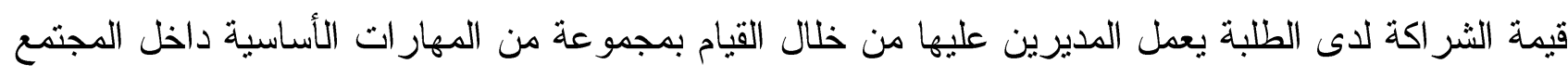
واستغلال بعض المناسبات ليشعروا بأهميتهم.

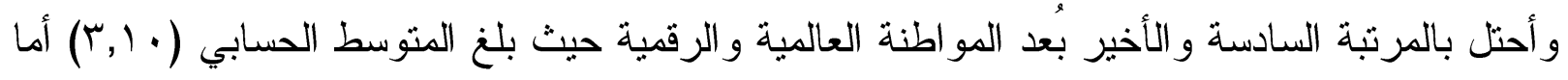

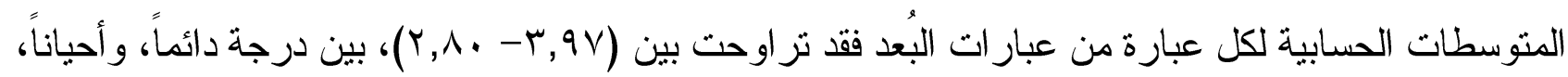

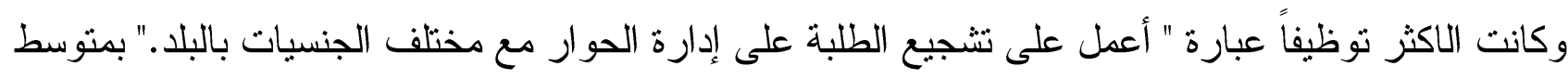

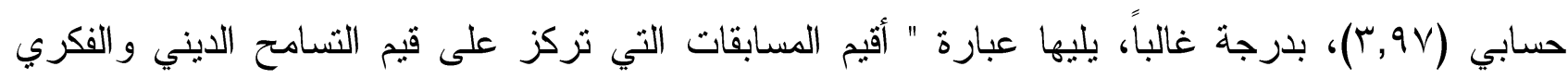

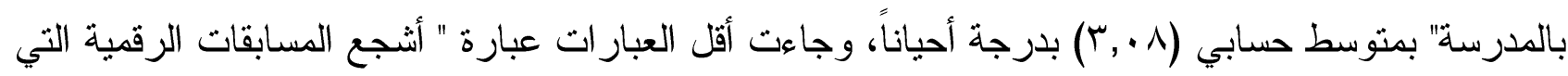

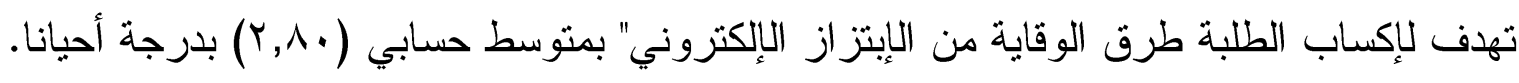

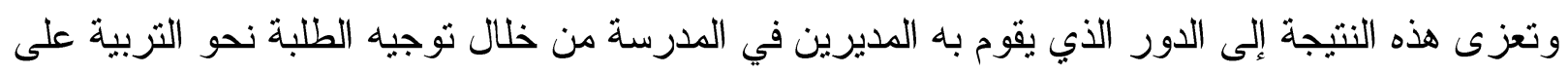
المو اطنة العالمية و الرقمية، خاصة أن المنهج المدرسي يشجع على تبني العديد من قيم السلام و التسامح و الاتصال التهال

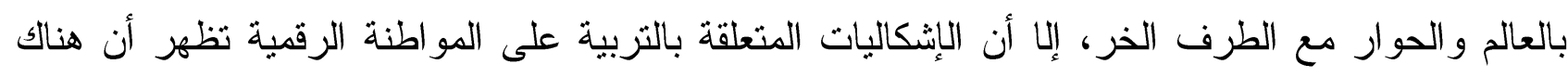

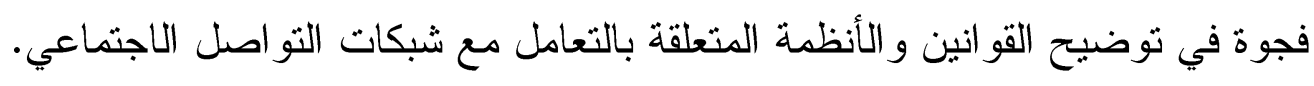
نتائج السؤال الثاني ومناقشتها: للإجابة عن السؤال الثاني الذي نصد: هل توجد فروق ذات دلالة الثالة إحصائية بين دور مديري المدارس في التربية

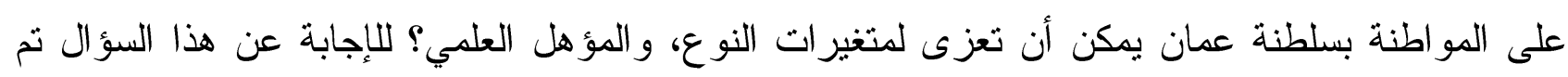

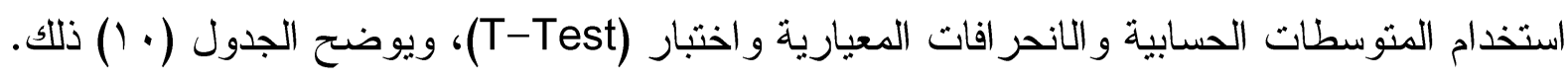
أولاً: النوع النوان النوع

جدول (1.)

المتوسطات الحسابية والانحر افات المعيارية واختبار (T-Test) تبعاً لمتغير النوع (1) لتول

\begin{tabular}{|c|c|c|c|c|c|c|c|}
\hline اتجاه & درجة ل & قيمة ت & الانحر اف & المتوسط & 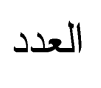 & نوع & أبعاد التربية على المواطنة \\
\hline 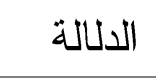 & 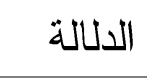 & & المعياري & الحسابي & & المدرسة & \\
\hline \multirow[t]{2}{*}{ غير داله } & ת & $\cdot, Y)$ & דיז, & r,Ar & 01 & ذكر & الإنتماء الوطني \\
\hline & & & $\cdot, r V$ & $r, \wedge)$ & or & أنثى & \\
\hline
\end{tabular}




\begin{tabular}{|c|c|c|c|c|c|c|c|}
\hline \multirow[t]{2}{*}{ غير داله } & \multirow{2}{*}{$\cdot, v \leq r$} & \multirow{2}{*}{ • } & $\cdot, \varepsilon V$ & $\varepsilon, O V$ & $0 \wedge$ & ذكر & \multirow[t]{2}{*}{ الهوية الوطنية } \\
\hline & & & • ( ا & $\varepsilon, 09$ & or & أنثى & \\
\hline \multirow{2}{*}{ غير داله } & \multirow[t]{2}{*}{ זמז, • } & \multirow[t]{2}{*}{$\cdot, 9 V$} & $\cdot, \varepsilon r$ & $\varepsilon, \mu q$ & $0 \wedge$ & ذكر & \multirow[t]{2}{*}{ الحقوق } \\
\hline & & & י r & $r, \varepsilon\rceil$ & or & أنثى & \\
\hline \multirow[t]{2}{*}{ غير داله } & \multirow[t]{2}{*}{$\cdot, r V I$} & \multirow[t]{2}{*}{$\cdot, \wedge 9$} & דו" & $\varepsilon, Y)$ & $0 \wedge$ & ذكر & \multirow[t]{2}{*}{ الو اجبات } \\
\hline & & & $\cdot, r V$ & $\varepsilon, Y V$ & or & أنثى & \\
\hline \multirow[t]{2}{*}{ غير داله } & \multirow[t]{2}{*}{ س } & \multirow[t]{2}{*}{., 99} & $\cdot, \leqslant q$ & $r, \varepsilon r$ & $0 \wedge$ & ذكر & \multirow[t]{2}{*}{ المشاركة } \\
\hline & & & $\cdot, \leqslant 0$ & r,ol & or & أنثى & \\
\hline \multirow[t]{2}{*}{ غير داله } & \multirow[t]{2}{*}{$\cdot, \wedge \vee \mu$} & \multirow[t]{2}{*}{$\cdot, 17$} & $\cdot, \cdot 7$ & $r, \cdot q$ & $0 \wedge$ & ذكر & \multirow[t]{2}{*}{ المو اطنة العالمية و الرقمية } \\
\hline & & & $\cdot, \cdot 7$ & ו ו & or & أنثى & \\
\hline \multirow[t]{2}{*}{ غير داله } & $\cdot, \varepsilon \circ Y$ & $\cdot, \vee \circ \varepsilon$ & • & $r, q r$ & $0 \wedge$ & & 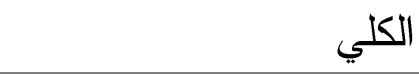 \\
\hline & & & $\cdot, Y_{1}$ & $r, q 7$ & $0 \wedge$ & ذكر & \\
\hline
\end{tabular}

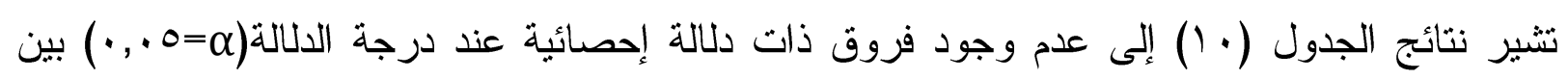
الذكور و الإناث في أبعاد التربية على المواطنة الستة، ويعزى ذلك إلى إعداد مديري المدراس وتثريبهم لا تختلف بين الذكور و الإناث. ثانياً: المؤهل العلمي.

تم استخر اج تحليل التباين الأحادي لمتوسطات أبعاد التربية على المواطنة، ويوضح الجدول (11) جدول (1 (1) تحليل التباين الأحادي لمتوسطات أبعاد التربية على المواطنة تبعاً لمتغير المؤهل العلمي

\begin{tabular}{|c|c|c|c|c|c|}
\hline \multirow[t]{2}{*}{ مستوى الدلالة } & \multirow[t]{2}{*}{ قيمة ف } & متوسط & درجات & مجموع & \multirow[t]{2}{*}{ مصدر التباين } \\
\hline & & المربعات & الحرية & المربعات & \\
\hline \multirow[t]{3}{*}{. roN } & דוr., & $\cdot, \wedge$. & r & 17. & بين المجمو عات \\
\hline & & $\cdot, \cdot V V$ & $1 \cdot 1$ & $\Lambda, M I Y$ & داخل \\
\hline & & & 11. & $\Lambda, \Sigma \vee Y$ & ع الكلي \\
\hline
\end{tabular}

تشير نتائج الجدول (1) إلى عدم وجود فروق ذات دلالة إحصائية عند درجة الدلالة(ه=ه . . ) لدور مديري المدر اس في التزبية على المواطنة بسلطنة عمان تعزى لمتغير المؤهل العلمي، ويعزى ذلك إلى الأدوار التي ينبغي أن يقوم بها مديرو المدر اس لا تتأثز بالمؤهل العلمي، أضف أن المعارف لديهم كانت و اضحة و هذا يعود إلى التدريب الذي يحصل عليها المديرين ما يتعلق بالتربية على المو اطنة.

توصيات الدراسة: في ضوء النتائج التي توصلت إلبها الدر اسة، يوصي الباحث بالآتي: 
ا ب. بناء محتوى تربوي متعلق بمبادئ المو اطنة وقيمها.

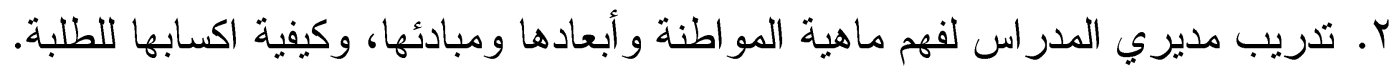
r. تضمين بر امج مديري المدر اس على التربية على المواطنة. ـ. تضمين برامج مديري المدر اس التربية على المواطنة العالمية والرقمية. ه. تطوير الأنشطة والجماعات الطلابية من أجل غرس القيم المواطنة من خلال الممارسات المدرسية و المجتمعية. I. تشجيع مديري المدر اس الطلبة على التعامل عبر شبكات التواصل الاجتماعي من أجل تدريبهم على القو انين و الأنظمة المتعلقة بالتو اصل الاجتماعي.

مقترحات الدر اسة:

يوصي الباحث إجر اء مجموعة من الدراسات المرتبطة بموضوع الدراسة الحالية، وهي كالآتي: 1. تحليل محتوى المناهج الدراسية ومدى تضمينها لفكر المو اطنة و أبعادها ومبادئها. r. دراسة البرامج التدريبية التي تقدم لمديري المدراس ومدى تأثيرها على ولى أداء المعلم في تتمية المو اطنة.

r. در اسة فاعلية الإدارة المدرسية في تتمية قيم المواطنة.

المرا: المر اجع

أولاً: المراجع العربية

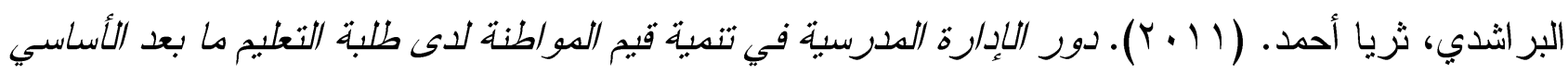

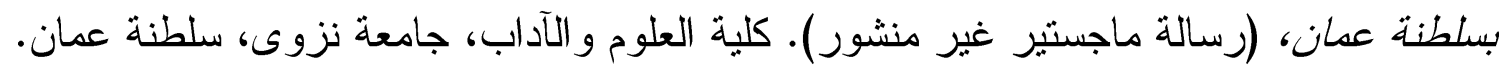

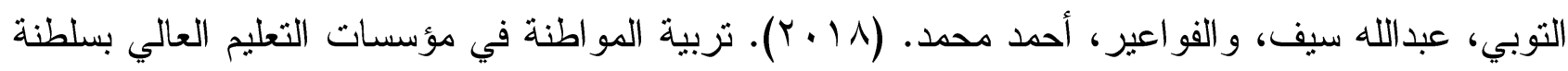

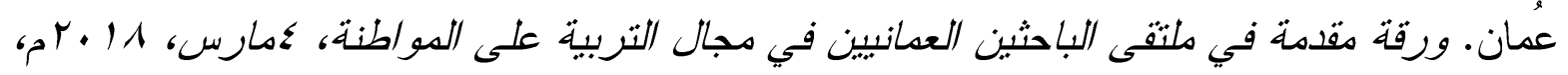
كلية التربية، جامعة السلطان قابوس، سلطنة عمان. الحامد، محمد بن معجب(2004). الثر اكة والتتسيق في تربية المواطنة، ورقة مقدمة للقاء الثالث عشر لقادة

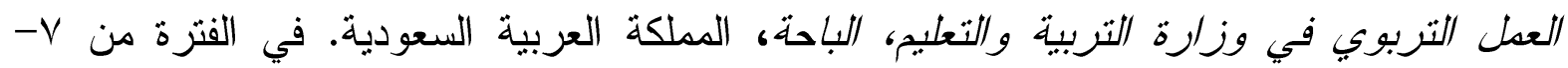

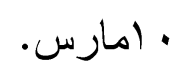

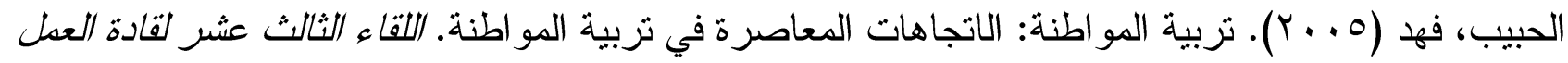

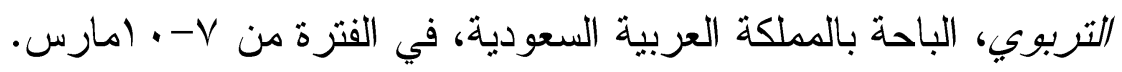

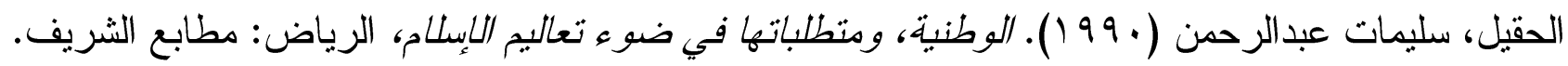

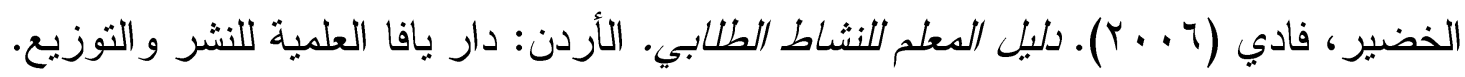

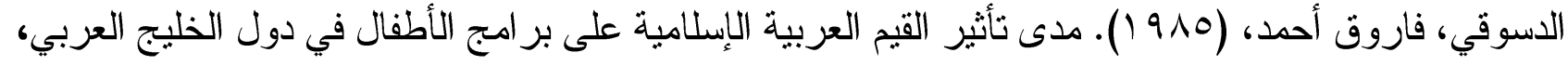

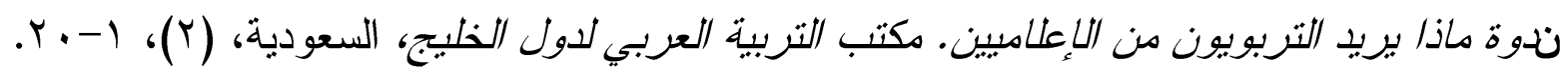

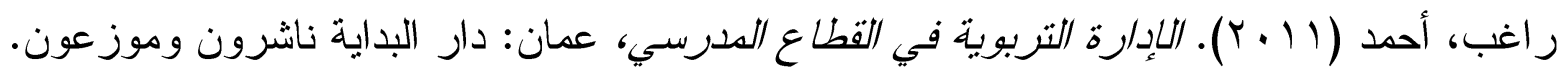


رجاء أحمد عيد، وآخرون(2008). ثقافة المواطنة الحلقة الأضعف في تدريس الدراسات الاجتماعية بالتعليم العام. المؤتدر الأول للجمعية الدصرية للاراسات الاجتماعية، تربية المواطنة ومناهج الدراسات

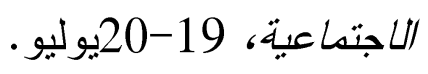

رضوان، أحمد؛ ويوسف، نهاية (10 • ب). تصور ات مديري المدر اس الحكومية في قصبة إربد لمعيقات تطبيق خطة النهوض الوطني لتعزيز الانتماء لاى الطلبة. مجلة جامعة النجاح للأبحاث (العلوم الإنسانبة).

رضوان؛ والحمد (Y ( Y Y). مساهمة المدرسة المديرين و المعلمين في تتمية الوعي السياسي لطلبة المرحلة

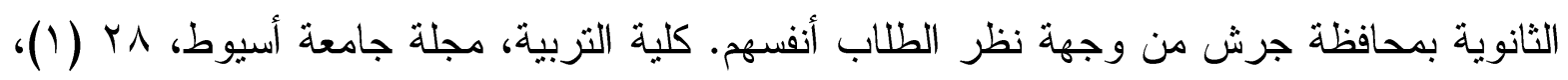
I $r \leqslant-9 \leqslant$ السعيدي، حميد بن مسلم (با • ب)، المواطنة المسؤولة، مقال بجريدة الرؤية، تاريخ النشر 2013/10/20، مسقط. السعيدي، حميد بن مسلم (Y V V). دور شبكات التواصل الاجتماعي في تعزيز أبعاد المواطنة لدى الثباب

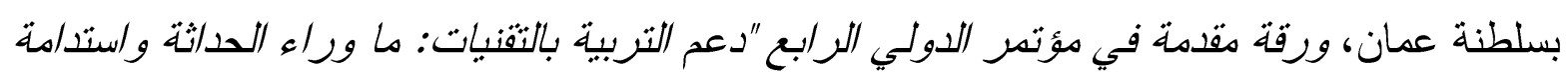

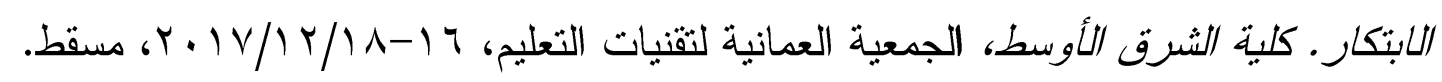

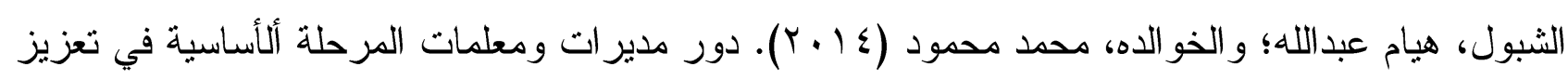

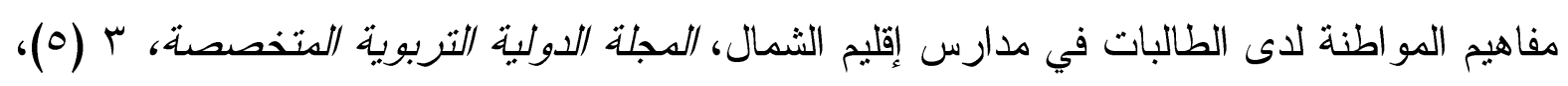
.9. -09

شعبان، وفاء (T ( • Y). التربية الدواطنية. بيروت: دار النهضة العربية.

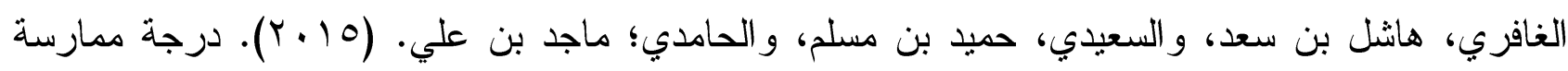

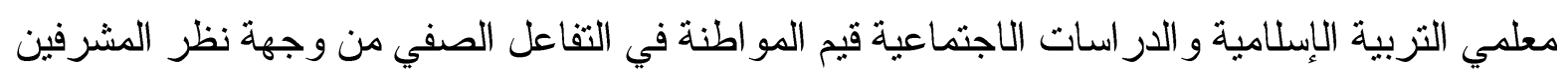

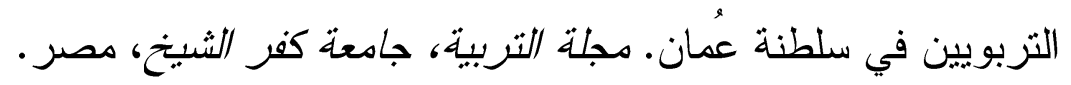

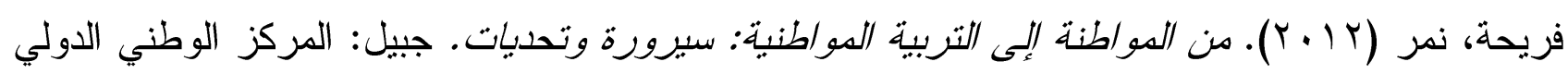
لعلوم الإنسان بيبلوس.

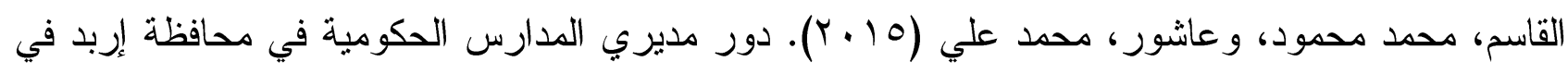

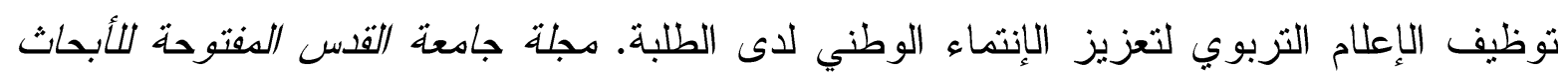

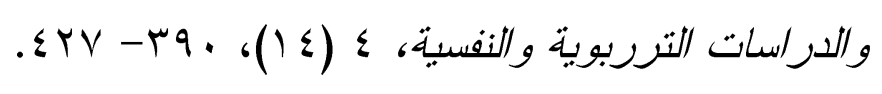

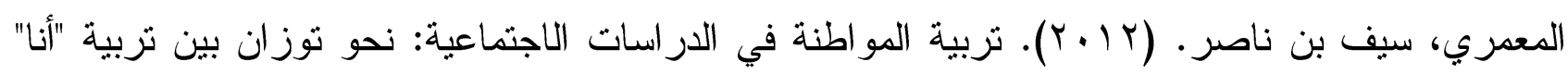

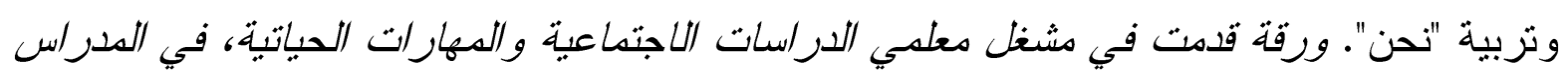

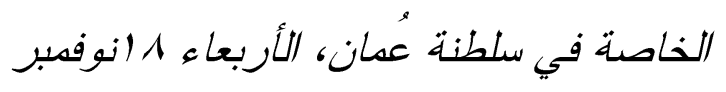




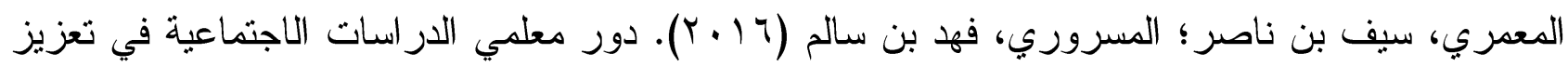

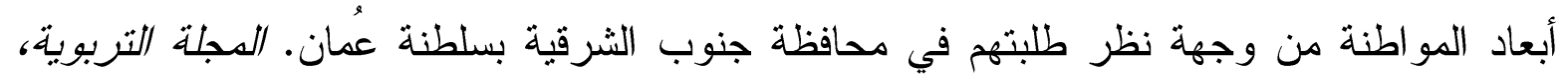

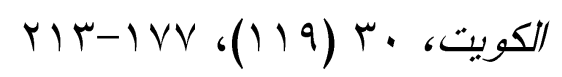

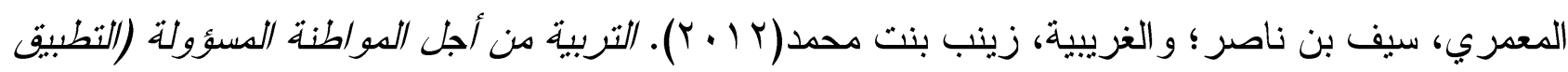
والنظرية)، مسقط.

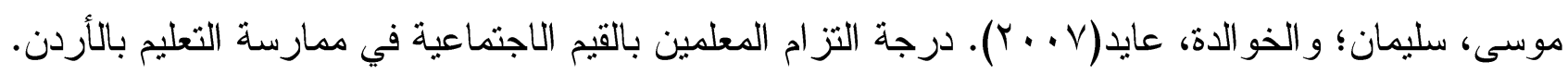

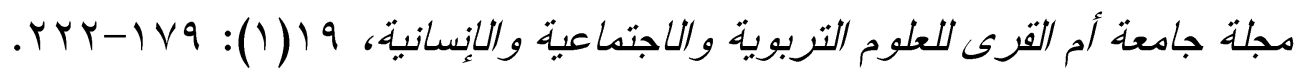

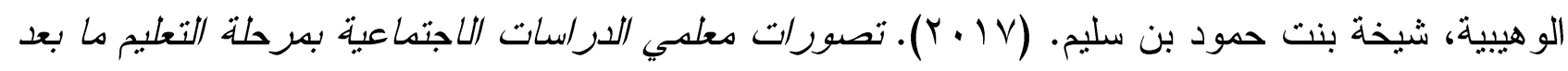
التعليم الأساسي في سلطنة عدان عن المواطنة الرقمية، (رسالة ماجستير غير منشورة). كلية النزبية،

$$
\text { ثانياً: المراجع الأجنبية. }
$$

Cangemi, J., Aucion, L.(1992) Attitudes of Teachers towards the teaching of selscted values. Education Resources Information Center (ERIC), ED356985.

Limos, R.,(1995) The nature of value. University of Florida press

Wagner (2004) Reviewed may 15. 2010, from: http//www.school evenfall, 04. Pdf.

Word, \& Bark, m, (2004), I'm proving achievement in low - perfuming Schools: key results for school leader. thousend oaks CA crowing press. Wagner (2004) Reviewed may 15. 2010, from: http//www.school evenfall, 04. Pdf. 